\title{
Prevention Practices and Legal Rules for Handling Pandemics in The Prophetic Sirah
}

\author{
"التطبيقات الوقائية والأحكام الشرعية الخاصية بالتعامل مع الأوبئة في السيرة والسنة النبوية "

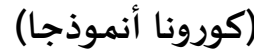 \\ حكيمة أحمد حفيظي \\ أستاذ الحديث وعلومه قسم السنة وعلومها كلية الشريعة وأصول الدين جامعة الملك خالد، أبها \\ المملكة العربية السعودية \\ Email:hakimahafidi61@gmail.com \\ فوزي بن موهوب \\ طالب في مرحلة إعداد رسالة الدكتوراه قسم الشريعة والقانون، جامعة الحاج لخضرو، باتنة، \\ الجزائر \\ Email: benmouhoubfouzi@gmail.com
}

Article Accepted: June 23, 2021, Revised: July 11, 2021, Approved: July 21, 2021

المللخص

تعد التطبيقات النبوية للوقاية من الأوبئة، واللجوء إليها في التصدي ل"كورونا"، من أهم ما ينبغي على

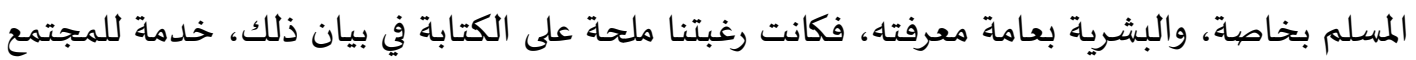

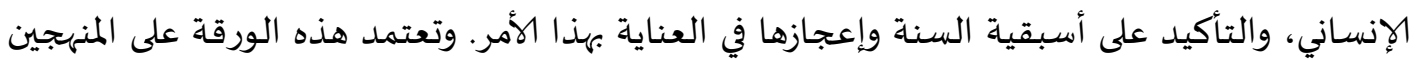

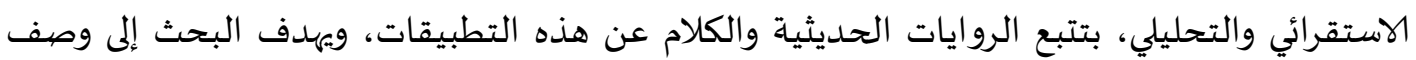

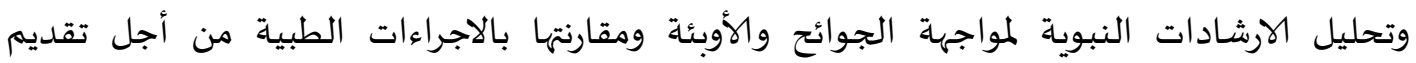

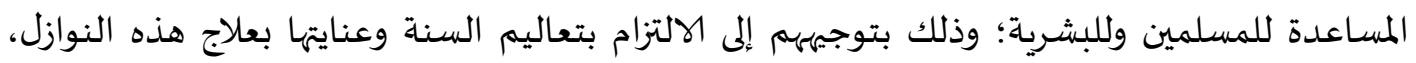

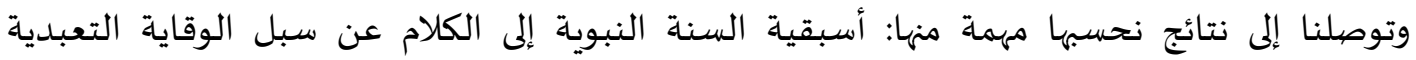
والاستشفائية من الأوبئة، وأن اللجوء إلى تعاليم الإسلام، وإلى تطبيقات السنة السنات النبوية وتوجيهاتها

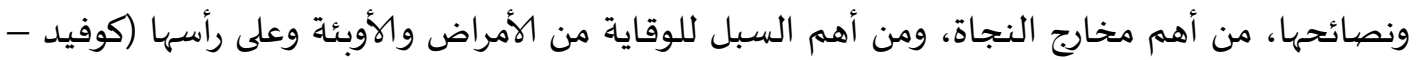

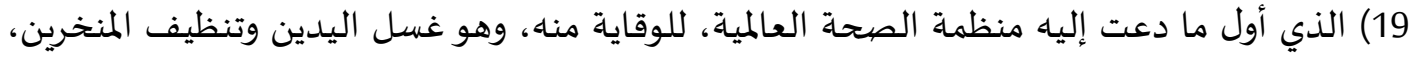

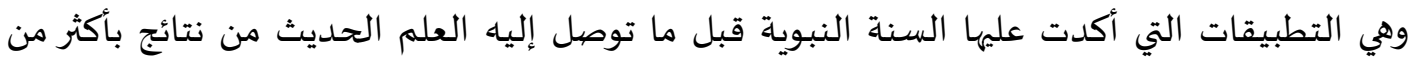
أربعة عشر قرنا، فكان فضل السبق والإعجاز للسنة. 


\begin{abstract}
This study focuses on highlighting the devotional and social preventive applications related to the epidemics, by shedding the lights on some stations from the biography and the sunnah of the Prophet peace be upon him, this will contribute in the prevention from epidemics, especially Corona virus, by following the teaching of Sharia and the approach of the Prophet, peace be upon him, in dealing with such types of epidemics that appeared in his era. To achieve the goal of this study, we followed two approaches: inductive and analytical. We start by presenting the Hadiths that dealt with the topic of prevention in the Sunnah and biography, then we analyze the most prominent methods and applications followed by the Prophet in the preventions of epidemics. The research reached the following results, most of them, the precedence of Sunnah through what was illustrated in the Prophet's biography in demonstrating the means of devotional and medical prevention against epidemics and their effectiveness in people's lives. Finally, worshipping by obeying orders and avoiding prohibitions is a reason to prevent the epidemic.
\end{abstract}

Key words: Sunnah, applications, Corona -virus, epidemics, preventive.

إن المتمعن في السنة النبوية والسيرة المصطفوية، يجد أنها تعاملت مع الأوبئة والجوائح بطرق فعالة، كانت

البشرية ولا زالت، وستظل في حاجة إلهها لمواجهتها؛ حيث جمعت بين السبل العقدية المتمثلة في الإيمان بأقدار الله قَّيَلْ، والإذعان إلى قدرته، واللجوء إلى رحمته، ورجاء عفوه ومغفرته، والضراعة إليه بالدعاء، ثم الأخذ بالأسباب الوقائية، والطبية، لحصول الشفاء، وذهاب البلاء، دون إغفال الكلام عن الأحكام التشريعية التي جاءت في القرآن الكريم والسنة النبوية، مبينين الأساليب العملية للتعامل مع الأوبئة. ولما كان كثير من المسلمين يدركون فعالية التطبيقات النبوية في مختلف المجالات الحياتية، ويؤمنون بنجاعة الأساليب النبوية في التصدي لمختلف النوازل، غير أههم يغفلون عن اللجوء إليها، جاء هذا البحث لينبه إلى أهمية التطبيقات النبوية الوقائية (التعبدية والاجتماعية) وفعاليتها في التعامل مع الأوبئة بعامة، والتصدي لما يستجد منها مثل: جائحة "كورونا" بخاصة. تكمن أهمية هذا الموضوع في جملة من النقاط منها: ما خلفته نازلة "كورونا" من آثار اللبية على الكرة الأرضية (عام 1441هـ/ 2020م)، خاصة ما حصدته من أرواح بشرية، وفعالية التطبيقات النبوية التشريعية، والوقائية في التعامل مع هذه الأوبئة. يسعى البحث إلى بيان أنواع الأوبئة التي ظهرت في عهد النبوة، والكلام عن التطبيقات النبوية في التعامل معها. لهذا سنركز في هذا البحث بخاصة في هذه الورقة على الكلام عن الأوبئة التي ظهرت في عهد النبي والتطبيقات النبوية في التعامل معها. وسعيا لتحقيق هذه الأهداف، يتوقع منا الإجابة عن التساؤلات الآتية: ما أنواع 
الأوبئة التي ظهرت في عهد النبوة؟ وما التطبيقات النبوية التشريعية، والوقائية للتعامل معها؟ وهل تنجو البشرية من أخطار ما يهددها من أوبئة لو تحصنت بالتطبيقات النبوية الشريفة؟ استعنا على تحرير هذا الموضيوع بمنهجين أساسين: الاستقرائي المقتصر على جمع الروايات والأحاديث النبوية المتعلقة بالموضوع، أما المنهج التحليلي فنستخدماه عند الكلام عن أنواع الأوبئة الفردية والجماعية التي ظهرت في عهد النبوة، والتطبيقات النبوية التشريعية والوقائية في التعامل معها، دون إغفالنا تخريج الروايات ذات الصلة، وبيان درجتها. إن ما يلاحظ على وباء "كورونا"، أنه على الرغم من كونه نازلة حديثة العهد بجميع البشرية اليوم، فإنها أسالت حبر المتخصصين في مختلف فروع العلوم الشرعية، والعلمية وغيرها، وسنكتفي في هذا المقام بذكر الدراسات المتعلقة بالعلوم الشرعية، مما وقفنا عليه أثناء إعداد هذا البحث، وما رأينا له علاقة بمحتواه. ففيما يتعلق بالأبحاث الأكاديمياة، نذكر: "هدايات السنة النبوية في التعامل مع الأوبئة جائحة كورونا المستجد (covid -19) أنموذجا، للدكتورة سندس عادل العبيد(1)، و"أثر قاعدة الضرر يزال على جائحة كورونا المستجد (19 - covid)"، للدكتور محمد علي الهدية(2)، و"نوازل الطهارة المتعلقة بجائحة كورونا - دراسة فقهية"، للدكتور ثامر المطيري، و"أحكام تعليق الصلوات في المساجد لمواجهة جائحة كورونا"، للدكتور آلاء العبيد، و"نوازل الصيام والحج المتعلقة بجائحة كورونا - دراسة فقهية"، للدكتور محمد العجمي، و"نظام الرقابة الشرعية على العمل الخيري في ضوء جائحة كورونا،" للدكتور محمد الفزيع، و"نوازل الزكاة المتعلقة بجائحة كورونا - دراسة فقهية تأصيلية"، للدكتور أحمد الحسينان، و"نوازل الوقف المتعلقة بجائحة كورونا دراسة فقهية تطبيقية،" للدكتورة مريم الأحمد، و"أثر قاعدة المشقة تجلب التيسير على جائحة فايروس كورونا وتطبيقاتها في باب العبادات"، للدكتورة منار الحربي(3)، و"الوقاية الصحية في السنة النبوية دراسة موضوعية"(4). ولا تقل عناية المؤسسات العلمية عن عناية العلماء والباحثين، بعقد ملتقيات ومؤتمرات دولية، وإقليمية، ومحلية للنظر في طبيعة هذا الوباء، والبحث عن علاجات وحلول للقضاء عليه واستئصاله، ومن ذلك: الندوة

1-1 بحث منشور في مجلة الشريعة والدراسات الإسلامية، فصلية علمية محكمة، تصدر عن جامعة الكويت، مايو 2020م.

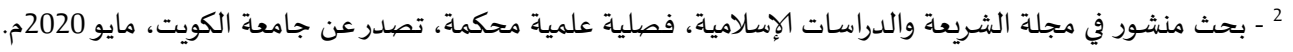

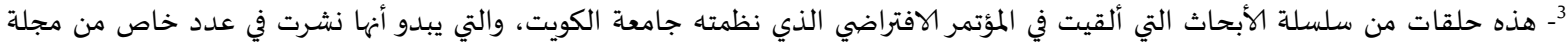

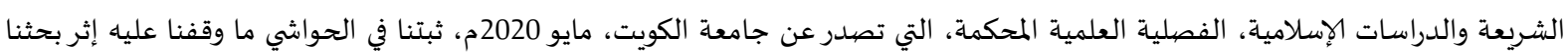


الطبية الفقهية الثانية "فيروس كورونا المستجد (كوفيد - 19) وما يتعلق به من معالجات طبية وأحكام شرعية"، التي عقدت عبر تقنية مؤتمرات الفيديو يوم 2020/04/16، إصدار مجمع الفقه الإسلامي الدولي، المنبثق عن منظمة التعاون الإسلامي؛ خرجت ب 24 توصية شملت: التعريف بالمرض، ومدى سماحة الفقه الإسلامي، وضرورة حماية النفس، وجواز فرض تقييدات على الحرية الفردية لما يحقق المصلحة، وأهمية النظافة والاحتياطات الخاصة بهذه الجائحة، ووجوب عزل المصاب والمشتبه با...الخ(5)، و"معالجة الشريعة الإسلامية لجائحة كورونا"، والمؤتمر الافتراضي الأول، الذي عقدته مجلة الشريعة والدراسات الإسلامية بالتعاون مع كلية الشريعة والدراسات الإسلامية، في الفترة 6 - 7/شوال/1441هـ، الموافق ل 29 - 30/يونيو/2020م، بمشاركة 26 بحثا. تتقاطع هذه الدراسات مع بحثنا في قضية الاستدلال بالآيات القرآنية، والأحاديث النبوية، كل وفق ما تقتضيه طبيعة موضوعه، وفيما عدا موضوع "الوقاية الصحية في السنة النبوية - دراسة موضوعية"، الذي اعتمدناه في مواضع الاستدلالات العلمية والطبية، كما هو مثبت في الحواشي، فلم تكن هذه الدراسات من موارد بحثنا، لجديتها، وعدم تمكننا من الاطلاع علها. ويختلف هذا البحث عن هذه الدراسات في نقطة اهتمامه بالتركيز على جوانب التطبيقات التشريعية والوقائية المتعلقة بالأوبئة، ومنها فايروس كورونا، من خلال وقفات وإطلالات من السيرة والسنة النبوية؛ وتتمثل إضافاته في عنايته بالكلام عن الوقائع الوبائية التي ظهرت في عهد النبوة، وعن التي نبأت بها السيرة النبوية، وتركيزه على إبراز التطبيقات (التعبدية والاجتماعية) الوقائية من الأوبئة، وعلى أحكامها الشرعية.

\section{منهجية البحث}

جعلنا البحث في مقدمة ومبحثين وخاتمة؛ تضمنت المقدمة أهمية الموضوع، وأهدافه، وإشكاليته، وأهم الدراسات السابقة فيه، ومنهجه، وأُفرِد المبحث الأول، للحديث عن الوقائع الوبائية الواردة في السيرة النبوية، والمبحث الثاني، للكلام عن التطبيقات الوقائية من الأوبئة، وأحكامها الشرعية، ثم انتهينا إلى خاتمة سجلنا فهها أهم النتائج والتوصيات.

oic - oic.org/topic/ - ينظر: توصيات ندوة "فيروس كورونا المستجد (كوفيد - 19) وما يتعلق به من معالجات طبية وأحكام شرعية" 


\section{المبحث الأول: الوقائع الوبائية الواردة في السيرة النبوية.}

المطلب الأول: الوقائع الوبائية الفردية.

روى الإمام مسلم من طريق عمرو بن الشريد عن أبيه قال: كان في وفد ثقيف رجل مجذوم، فأرسل إليه

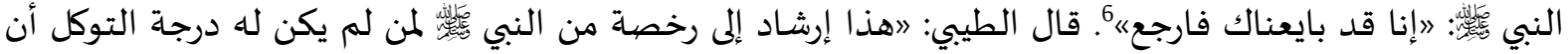
يراعي الأسباب، فإن لكل شيء من الموجودات خاصية وأثرا أودعها فيه الحكيم جل وعلا《. روى الإمام البخاري من طريق عبد الله بن معقل قال: جلست إلى كعب بن عجرة8 فسألتهاه عن الفدية؟ فقال: نزلت فيَ خاصاة، وهي لكم عامة، حملت إلى رسول الله الجهد بلغ بك ما أرى ـ تجد شاة؟《 قلت: لا، فقال: 》فصيم ثلاثة أيام، أو أطعم ستة مساكين، لكل مسكين نصف

روى الإمام البخاري من طريق هشام بن عروة عن أبيه عن عائشة رضي الله عنها أنها قالت: لما قدم رسول

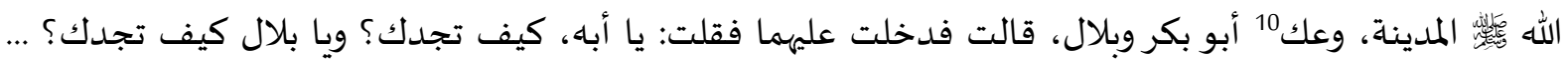

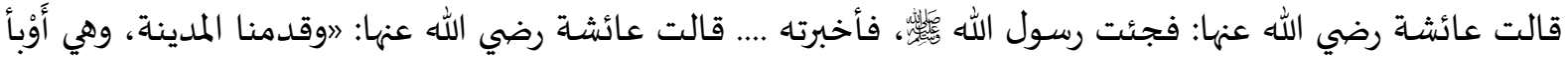
أرض الله، وكان بطحان يجري نجلا، يعني: ماءً آجنًا «112. وقال زياد عن محمد بن إسحاق بسنده إلى عائشة رضي

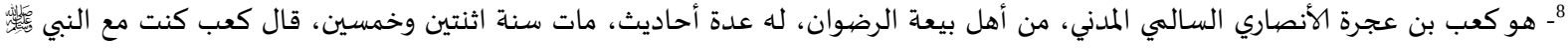

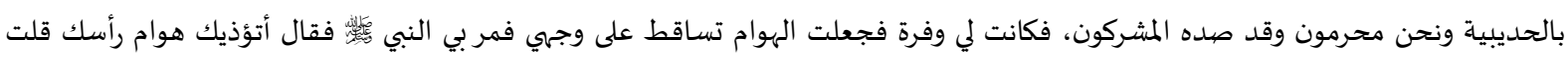

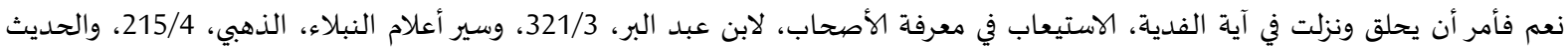

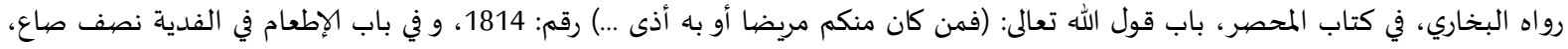
رقم: 1816، ومسلم، في كتاب الحج، باب جواز حلق الرأس للمحرم ....، رقم:

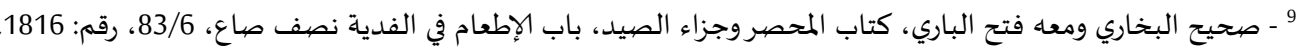

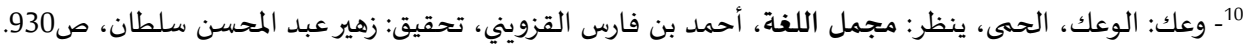

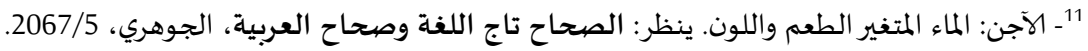

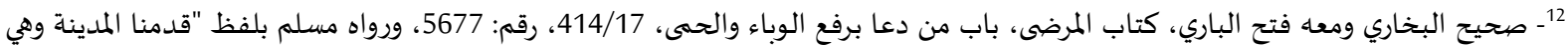

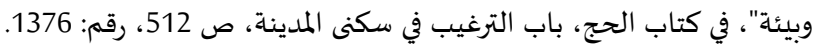


الله عنها قالت: لما قدم رسول الله وسقم ....

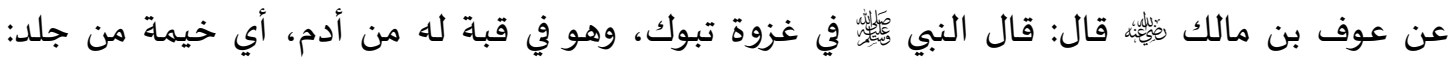

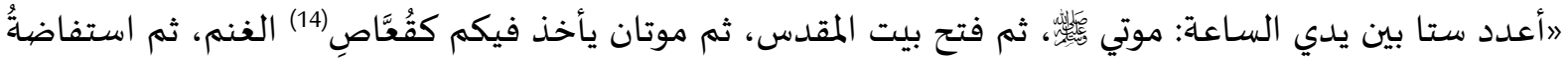
المال حتى يُعطى الرجل مئَة دينار فيضَلُ ساخطًا، ثم فتنة لا يَبقى بيت من العرب إلادخلته، ثم هُدنة تكون بينكم وبين بني الأصفر، فيغدرون فيأتونكم تحت ثمانين غاية تحت كل غاية اثنا عشر ألفا《15. . عن عائشـة -رضى الله

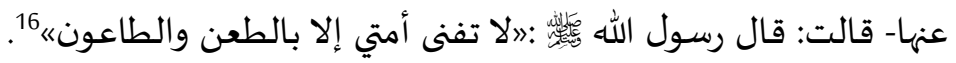

المبحث الثاني: التطبيقات الوقائية من الأوبئة وأحكامها الشرعية من خلال السيرة النبوية الأمراض المعدية بين الناس ليست وليدة العصر الحديث، بل يرجع ظهورها إلى عصور غابرة؛ وفي كل حقبة يتعامل معها البشر بأساليب معينة، ونحن إذ نلاحظ في هذا العصر (2019 - 2020)، ظهور أمراض معدية كثيرة جداً، كإنفلونزا الطيور، وإنفلونزا الخنازيروالملاريا، والسارس، والإيبولا، وعلى رأسها وباء كورونا الذي ظهر في مستهل السنة الميلادية 2020، ومن هذه الأوبئة ما استطاعت البشرية التغلب عليه، بإيجاد أدوية ولقاحات مضادة، ومنها ما استعصى على العلماء مكافحته مثل كورونا، التي أضحت جائحة حصيدت من البشر مثلما تحصد النارمن الهشيم؛ ما دفعنا إلى اللجوء إلى سنة رسول الله صلى الله عليه وسلم، وسيرته العطرة، للبحث في سبل تعامله مع الجوائح، رغبة منا في تنبيه البشرية إلى الاطلاع على منهج النبي صلى الله عليه وسلم، في علاج مثل هذا الوباء.

المطلب الأول: التطبيقات التعبدية الوقائية من الأوبئة في السيرة النبوية وأحكامها. عبادة الله عز وجل هي الغاية التي خلَق الله من أجلها الخلْق قال تعالى: "وَمَا خَلَقْتُ أُلْجِنَّ وَالِِنْسَ إِلَّا لِيَعْبُدُوِِِّ" [الذاريات: 56]، لذا كان التعبد الله تعالى إجمالا، والتقرب إليه بالصالحات، مما يقي العبد المسلم من

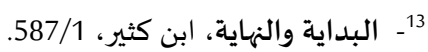

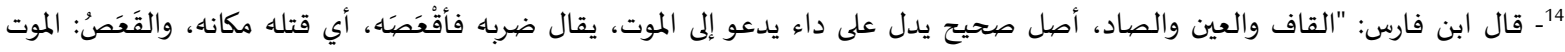

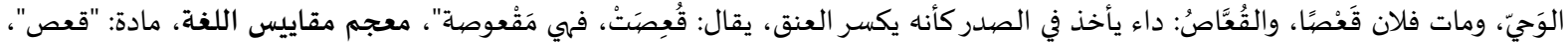


المصائب في روحه وبدنه، ومن ذلك عبادات يتقرب بها إلى الله عز وجل، طلبا للشفاء، وصرف الأوبئة، الأمر الذي جعل أحكام الشريعة الإسلامية، تتميز عن غيرها، بما جاء فيها من سبل وقائية، تستشرف الدواء قبل وقوع الداء، وتصف الشفاء قبل نزول الوباء، نذكر منها الآتي: الفرع الأول: الدعاء.

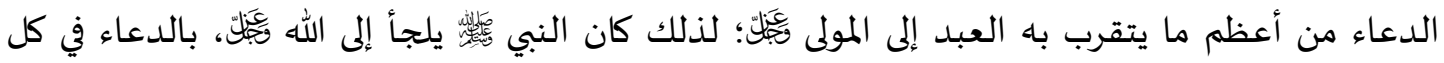
حين، وعلَّم الأمة من الأدعية ما تفتح به أبواب السماوات، وتنكشف به الكربات، وتصرف به الأوبئة والأزمات. فعن عائشة رضي الله عنها، قالت: قال النبي الجحفة، اللهم بارك لنا في مدنا وصاعنا«17. قال ابن بطال: افيه من الفقه جواز الدعاء إلى الله تعالى في رفح الوباء والحمى والرغبة إليه في الصحة والعافيةة"18، وقال ابن حجر في معرض رده على من ينكر التعبد بالدعاء: 》وأجيب بأن ذلك لا ينافي التعبد بالدعاء، لأنه قد يكون من جملة الأسباب في طول العمر أو رفع المرض، وقد تواترت الأحاديث بالاستعاذة من الجنون والجذام وسيء الأسقام، ومنكرات الأخلاق والأهواء والأدواء، فمن ينكر التداوي بالدعاء يلزمه أن ينكر التداوي بالعقاقير، ولم يقل بذلك إلاشذوذ، والأحاديث الصحيحة ترد عليهم وفي الالتجاء إلى الدعاء مزيد فائدة ليست في التداوي بغيره، لما فيه من الخضوع والتذلل للرب سبحانه، بل منع الدعاء من جنس ترك الأعمال الصالحة اتكالا على ما قدر فيلزم ترك العمل جملة ورد البلاء بالدعاء كرد السهم بالترس《19. ومن الأدعية الواردة عن النبي فقال: "من هذه؟ " قالت: أُمٌّْ مِلْدَم، قال: فأمر بها إلى أهل قباء، فَلَقُوا ما لا يعلم إلَّا الله، فأتوه، فَشَكَكوا ذلك إليه، فقال: "ما شئتم؟ إن شئتم دعوت الله ليكشفها عنكم، وإن شئتم تكون لكم طهورًا"، قالوا: أوَ تفعل؟ قال: "نعم"،

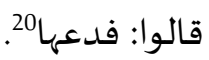

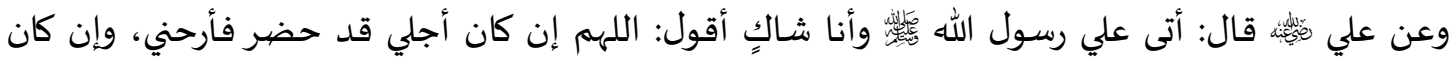
متأخرا فارفعني، وإن كان بلاءًا فصبرني، فضربني برجله، وقال: 》كيف قلت؟ه فأعدت عليه، فقال: 》اللهم اشفهش أو

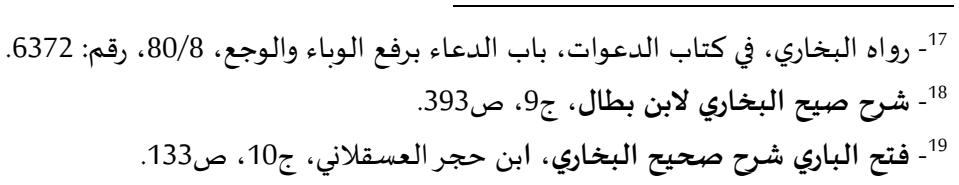

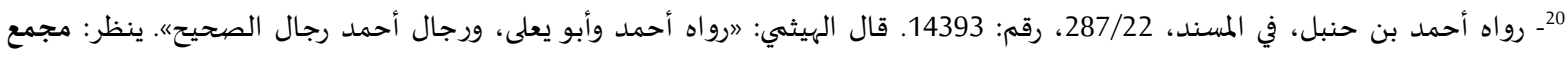
الزوائد ومنبع الفوائد، الهيثهي، 306/2 المندي، 
قال: 》اللهم عافهش، قال علي: فما اشتكيت وجعي ذلك بعد.21. اللهم إني أعوذ بك من البرص، والجنون، والجذام

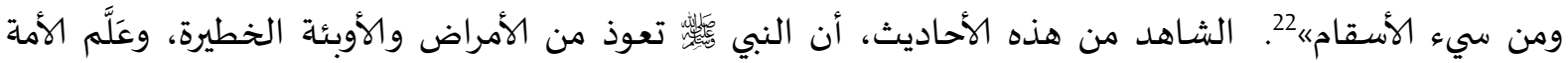
الأدعية النافعة، التي تعتبر من باب إظهار العبودية لله تعالى، الذي بيده النفع والضر، فهو القادر وحده على رفع الأسقام، والدعاء من بين الأساليب الناجعة لردها مع فعل الأسباب الدافعة كالتوحيد الخالص، وبر الوالدين،

الفرع الثاني: الطهارات التعبدية وأثرها في الوقاية من وباء كورونا المستجد.

تعد الطهارة في الإسلام، مفتاح العبادة وباب من أبواب الوقاية للحفاظ على الصحة، وتنقسم إلى قسمين طهارة نفس، وطهارة جسم؛ فطهارة النفس: كترك الذنوب، والعمل الصالحات، وتنقيتها من العيوب..، وطهارة الجسم: كرفع الحدث، وإزالة النجاسـ، وغيرها، وكلها عبادات لها أثرها البالغ في حفظ النفس والجسم من الأمراض والأوبئة، وقد نوه النبي لكئ山 في سيرته العطرة على ذلك، وأمر أمته أن تتطهر، وتحافظ عليها، وجعلها شطر الإيمان فقال: 》الطهور شطر الإيمان«23، وفيما يلي نبرز أهمية الطهارة التعبدية في الوقاية من الأمراض والؤبئة:

أولا: الوضوء وأثره في الوقاية من وباء كورونا المستجد.

عنى النبي

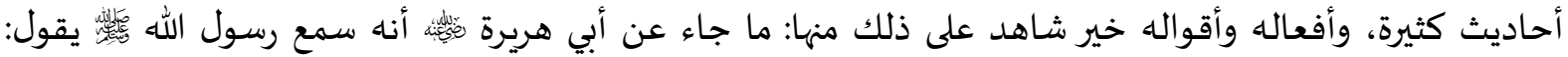
״أرأيتم لو أن نهرا بباب أحدكم يغتسل فيه كل يوم خمسا، ما تقول: ذلك يبقي من درنهه قالوا: لا يبقي من درنه

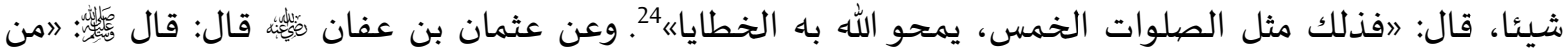
توضأ فأحسن الوضوء خرجت خطاياه من جسده حتى تخرج من تحت أظفاره؛25.

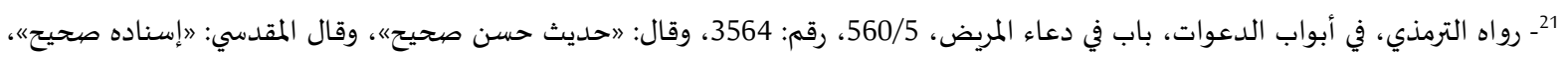

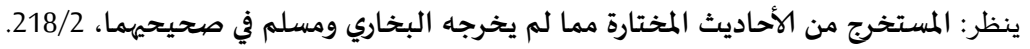

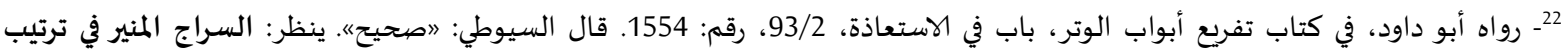

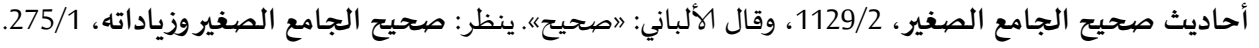

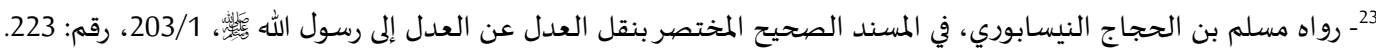

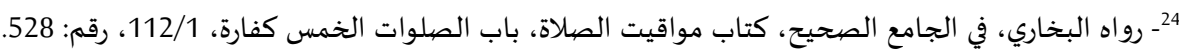

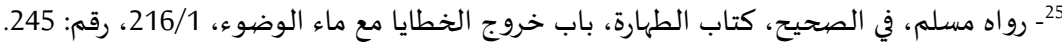


وعن عطاء بن يسار عن ابن عباس، أنه لتوضاً فغسل وجهاه، أخذ غرفة من ماء، فمضمض بها واستنشق، ثم أخذ غرفة من ماء، فجعل بها هكذا، أضافها إلى يده الأخرى، فغسل بهما وجهه، ثم أخذ غرفة من ماء، فغسل بها يده اليمنى، ثم أخذ غرفة من ماء، فغسل بها يده اليسرى، ثم مسح برأسه، ثم أخذ غرفة من ماء، فرش على رجله

اليمنى حتى غسلها، ثم أخذ غرفة أخرى، فغسل بها رجله، يعني اليسرى《 ثم قال: هكذا رأيت رسول الله ئه يتوضأ26. الشاهد من الأحاديث، أن الوضوء خمس مرات في اليوم بهذه الكيفية يجعل المسلم في أعلى درجات النظافة، و يقيه من الجراثيم والميكروبات والفيروسات؛ إذ يعتبر خط الدفاع الأول لسلامة الجسد، وقد ثبت علميا "أن للوضوء تأثيراً فعالاً على طهارة جسم المسلم؛ عند تنظيف الأنف والفم، المعبران الأساسيان لوصول الجراثيم والفطريات والبكتيريا إلى داخل الجسم، وتطهيرهما بالوضوء خمس عشرة مرة على الأقل، في اليوم، عن طريق الاستنشاق والاستنثار مما يمكن أن يلتصق بهما من عوالق من بقايا الطعام، والبكتيريا في الفم، والأتربة والفطريات والجراثيم، والقشور، والافرازات المخاطية من الأنف والجيوب الأنفية، وغير ذلك من الملوثات التي تنتشر في الغلاف الغازي للأرض، وسرعان ما يتنفسها الإنسان عن طريق الأنف والفم"727. ونظرا لانتقال فيروس كورونا عبر قناتي الانف والفم فوجب الحرص والمبالغة في الاستنشاق والاستنثار في الوضوء، لاستخراج ما تعلق بالفم والأنف من الشوائب المساهمة في نقل الفيروس إلى الجهاز التنفسي وهو ما يؤكد الإعجاز التشريعي والعلمي للإسلام حيث جاءت توصيات منظمة الصحة العالمية موافقة لما عليه تعاليم الإسلام بتأكيد على لزوم النظافة العامة وغسل اليدين بخاصة بوصفهما السبيل الأول للوقاية من هذا الوباء القاتل وهذه المطابقة ليست على سبيل الصدفة، بل فيها دلالة على صحة المنهج الإسلامي في الوقاية الصحية وأسبقية السنة إلى

أمر كُّأ المسلمين بالغسل عند الحدث الأكبر، كالجنابة، والحيض، وصلاة الجمعة، والعيدين وغيرها، من أجل المحافظة على صحة الجسم، ووقايته من الأوبئة والأدران؛ فحدد المدة التي لا يمكن للمسلم تجاوزها بغير غسل،

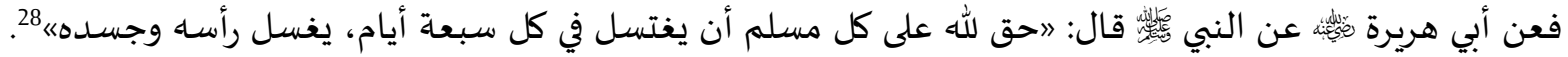

26ـ رواه البخاري، في كتاب الوضوء، باب غسل الوجه باليدين من غرفة واحدة، 40/1، رقم: 140.

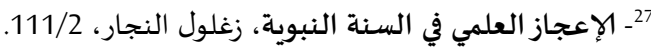

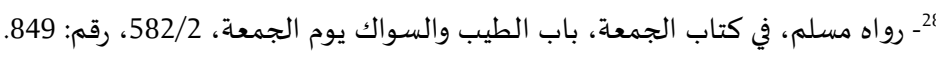


وقد أثبت الطب الحديث أن: "الجلد يعتبر مخزناً لنسبة عالية من البكتيريا والفطريات، التي تكثر على البشرة وجذور الشعر، ويتراوح عددها من 10000 إلى 100000 جرثومة في كل سنتيمتر مربع من الجلد، وفي المناطق المكشوفة منه، يتراوح العدد بين 1000000 إلى 5000000 جرثومة في السنتمتر الواحد، وترتفع هذه النسبة في الأماكن الرطبة كالإبط، والعانة، إلى 1000000 في السنتمتر الواحد، والغسل والوضوء خير مزيل لهذه الكائنات؛ فإن الاستحمام يزيل 90\% منها، أي أكثر من 200000000 جرثومة في المرة الواحدة، وهذه الجراثيم تلتصق بالجلد بواسطة أهداب قوية؛ لذا أمر الشارع بتدليك الجلد في الوضوء والغسل"29. وكما يعمل الغسل على فتح المسامات التي تنسد بالعرق كي يستعيد البدن نشاطه من جديد، وهذا يوافقه العلم الحديث في أن: "جسم الإنسان، وبالأصح جلده الخارجي، مكون من آلاف المسام التي تغطيه وتفرز مادة ترطب الجسم، وتعطيه شيئاً من الحيوية عند اشتداد الحرارة، تلك المادة التي تدعى العرق وتكاثر هذه المادة، وتجمعها فوق الجلد، مع ما في الجو من غبار، وما يحمله الهواء من الهوام وغيرها، يؤدي إلى انسداد هذه المسام بصورة جزئية أو كلية؛ مما يحتاج معاه الإنسان إلى إجراء غسل لسائر جسده، كي يستعيد هذا البدن قوته ونشاطه، ويستمر في عطائه وحيويته فوق الأرض؛ وقد كانت السنة النبوية سباقة إلى الدعوة إلى الاغتسال قبل ذلك بأكثر من أربعة عشر

\section{ثالثا: الطهارة من الخبث وأثرها في الوقاية من الأوبئة.}

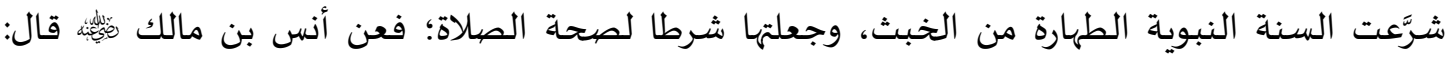
״كان رسول الله والجراثيم؛ لذلك شدد النبي عباس رضي الله عنهما قال: مر رسول الله

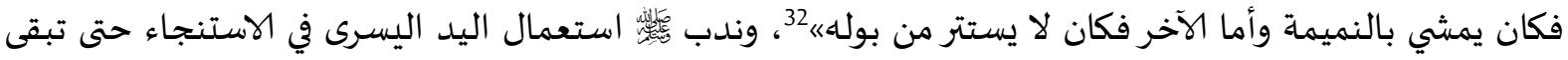

$$
\begin{aligned}
& \text { 29- الوقاية الصحية في السنة النبوية، العيد بلالي، ص27. }
\end{aligned}
$$

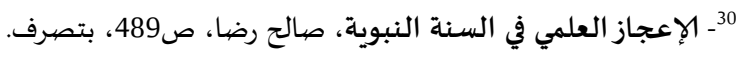

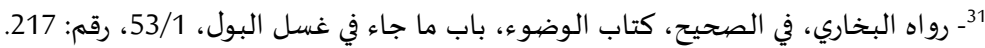

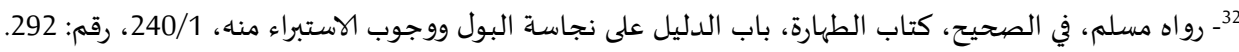




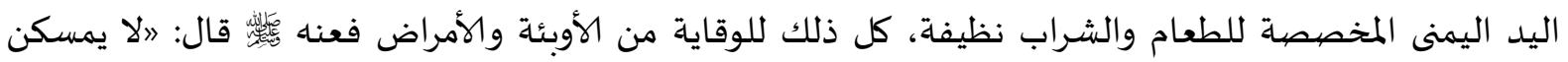
أحدكم ذكره بيمينه وهو يبول ولا يتمسح من الخلاء بيمينه ولا يتنفس في الاناء《33. وقد مضى على نزول الوحي بهذه الشرائع على رسول الله صلى الله عليه وسلم قرابة أربعة عشر قرنا، لتتفطن الدول الغربية، إلى هذه السبل، وتجعلها من السبل الناجعة للحد من انتشار الأوبئة في زمن الجوائح: ففي عام 1963م انتشر مرض التيفوئيد في مدينة "داندي بانجلترا" بشكل عاصف، وأصاب السكان بالذعر الشـديد وبذل الجميع قصارى طاقاتهم لوقف انتشار المرض، وفي النهاية اتفق العلماء على إذاعة تحذير في مختلف وسائل الإعلام يأمرون فيه الناس بعدم استعمال الأوراق في دورات المياه واستبدالها باستخدام المياه مباشرة في النظافة؛ ليتوقف انتشار العدوى، فاستجاب الناس، وكانت النتيجة العجيبة، أن توقف فعلاً انتشار الوباء، وتمت محاصرته4.

رابعا: سنن الفطرة وأثرها في الوقاية من الأوبئة. تعد سنن الفطرة الخمس التي أمر النبي والؤبئة عموما ووباء كورونا المستجد خصوصا، الذي أثبت الطب الحديث أن من بين أسباب انتشاره قلة النظافة الجسدية ويعد ترك سنن الفطرة من بين أكثر أسباب الأوساخ في عدة مواضع من الجسم مما يفضي إلى تكاثر الجراثيم والفيروسات خاصة مع تكرار استعمال الوسائل الحديثة المستعملة في عملية التنظيف أو تبادلها بين الأفراد، وقد جاء الحث على سنن الفطرة في حديث أبي هريرة عن النبي الفطرة: الختان، والاستحداد، ونتف الإبط، وتقليم الأظافر، وقص الشارب《35، ويظهر من الحديث السابق أن المواضع التي أمر المسلم بتنظيفها منها ما يعد مخرجا للسموم، كالعرق والبول، ومنها ما يعد تركه وعدم تعديله بما يوافق الفطرة مدخلا للسموم والميكروبات والفيروسات، وفيما يلي بيان أهمية هذه السنن في الوقاية من الأوبئة: أثر الختان والاستحداد ونتف الابط في الوقاية من الأبوبئة: يتعلق الختان والاستحداد ونتف الإبط بمواضع حساسة في الجسم؛ حيث تعد مخرجا لعدة سموم واستبقاؤها في الجسم قد يضعف مناعته، للختان 33ـ رواه مسلم، في الصحيح، كتاب الطهارة، باب النهي عن الاستنجاء باليمين، 225/1، رقم: 267.

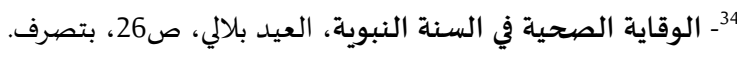

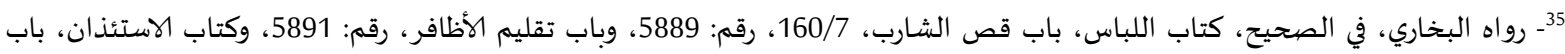

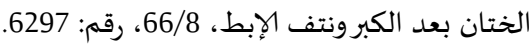


فوائد صحية كثيرة، لما يحققه من طهارة ونظافة للمختونين، وقد أكد الطب على أن بقاء القلفة محيطة بالحشفة يكون بمثابة المستنقع الذي تنمو فيه أكثر العوامل المرضية، ويسقيها البول بنجاسته فتتكاثر وتنتعش، وقد تسبب العقم عند الرجال نتيجة التهاب الخصية، كما ثبت أن الختان يمنع سرطان رأس القضيب؛ إذ لا يوجد لهذا السرطان أثر عند المختونين36. كما أن الاستحداد من سنن الفطرة التي أكد عليها النبي ״وقّت لنا في قص الشارب، وتقليم الأظافر، ونتف الإبط، وحلق العانة، ألا تترك أكثر من أربعين ليلة《37؛ فالاستحداد له أثر بارز في حماية المسلم من الأمراض والأوبئة؛ لأن هذا الموضع من الجسم عرضة للنجاسات، التي تتسبب في أمراض كثيرة، كأمراض الجهاز البولي والأمراض التناسلية، والآفات الجلدية، التي قد تتعدى إلى أفراد الأسرة عن طريق الحمام، وإلى أبناء المجتمع عن طريق حوض السباحة العام وغيرها. في حين أن نتف الإبط يخفف من الرائحة الكريهة، ومن الإصابة بالعديد من الأمراض التي تصيب تلك المنطقة، كالمذح، والسعفات الفطرية، والتهابات الغدد العرقية، والتهاب الأجربة الشعرية وغيرها، كما يقي من الإصابة بالحشرات المتطفلة على الشعر كقمل العانة38؛ ومن ثم فتعد هذه التوجيهات النبوية، والتطبيقات المصطفوية، من أنجع السبل في الوقاية من انتشار الأوبئة عند الشخص الواحد، أو انتقالها عبر الملامسة والاحتكاك والتقارب بين مجموعة كثيرة من الأفراد، بل بين ملايين من أفراد المجتمع البشري، كما هو الحال بالنسبة لفيروس كورونا، وقد أكدت الأبحاث العلمية والتجارب المخبرية على ذلك، ودعت البشرية إلى التقليل من الاختلاط والتقارب، وإلى غسل الأيدي لأنها من أبرز الأوعية الناقلة للفيروسات.

$$
\text { أثر تقليم الأظافروقص الشارب في الوقاية من الأوبئة: }
$$

تعد الأظافر والشارب من المواضع الخارجية التي بإمكانها إدخال أضراراً لجسم الإنسان، وذلك لما تحمله من

$$
\text { الأوساخ والميكروبات، والفيروسات المتنقلة عبر الجهاز التنفسي من الأنف والفم. }
$$

إن نظافة الأظافر بتقليمها، يقي من نقل الفيروسات وتكاثرها كما يحصل عند الطيور والجوارح، فعن أبي

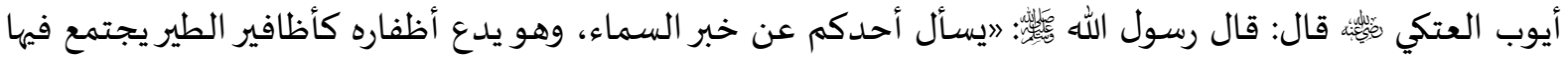

36 - الوقاية الصحية في السنة النبوية، ص32.

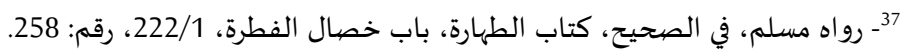

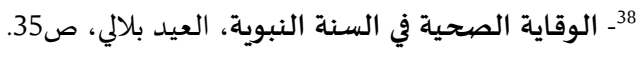




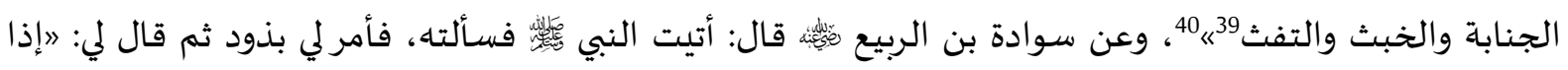

رجعت إلى بيتك فمرهم فليحسنوا غذاء رباعهم، ومرهم فليقلِّموا أظفارهم، ولا يعبطوا بها ضروع مواشههم إذا حلبوا《14. الشاهد من هذه الأحاديث، أن الأظافر الطويلة تجمع تحتها الأوساخ التي قد تمنع من إزالة الجنابة ووصول الماء إلى الجلد، وقد تسبب جرح ضروع الأنعام؛ ولهذا أمر عليه الصلاة والسلام بتقليمها للوقاية من هذه الأمراض. أما الشارب فقد كان الداعي إلى جزه مقربته من الفم والأنف، واحتمال تسرب ما يَعْلَقُ به من الخبائث

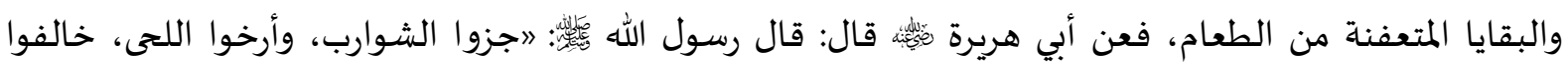
المجوس،«2؛ فإطالة الشارب طبيا، إذا ما تلوثت بالطعام والشراب، من أسباب نقل الجراثيم، وسنة الإسلام في قص الشوارب ما زاد عن الشفة العليا فقط، تتفق مع ما دعا إليه الطب، كما أن الشارب خلق للرجل وهو المهياً للعمل وطوارئ البيئة، ووجود الشارب يحمي الرجل من طوارئ البيئة وتصفية الهواء الداخل عبر الأنف إلى الرئتين، وقصيه أنفع وأسلم 43. ومنه فكلا من طول الأظافر والشارب قد ينقل الفيروسات كما أثبت الطب الحديث، وفيروس كورونا المستجد لا يستبعد مساهمة الأظافر الطويلة المتسخة والشـارب المتدلي على الفم والمُّفلق للأنف في نقله بين الناس خاصة في حالات الاختلاط والمطعم والمشرب.

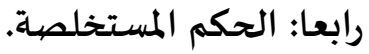

نستخلص مما سبق أن الطهارات المأمور بها شرعا لها دور في الوقاية من الأوبئة الفتاكة، ويظهر هذا من

خلال التدابير الوقائية التي تدعو إلى الحرص على النظافة الجسدية، وقد أثبت العلم الحديث فعالية الطهارة الإسلامية في الوقاية من وباء كورونا، لكونها متسقة مع ما تدعو إليه منظمة الصحة العالمية، من التزام النظافة،

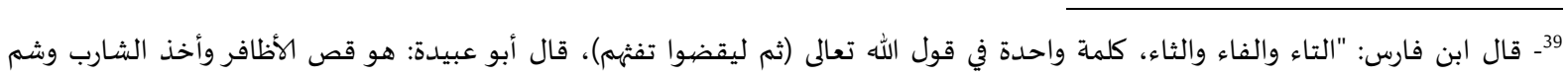

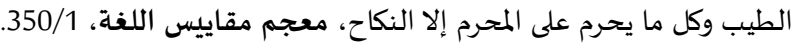

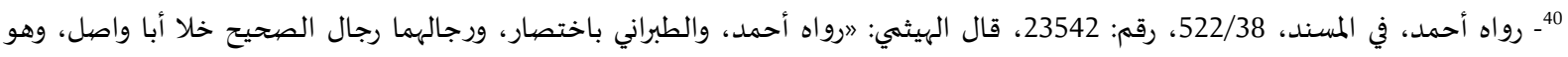

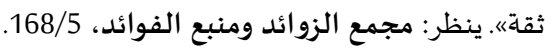

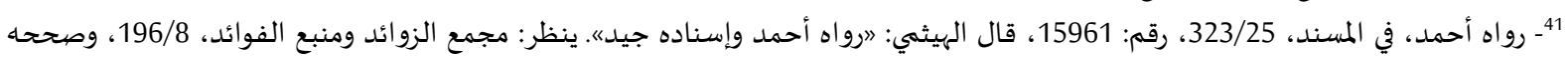

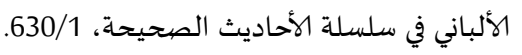

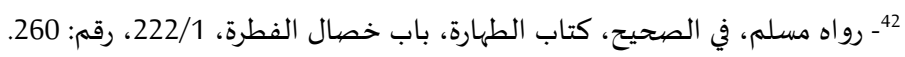

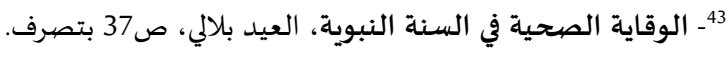


والتعقيم. وفي حالة فشو وباء ما، كما هو في نازلة كورونا المستجد، يتأكد على المسلم الحرص على الطهارات الواجبة، وعدم التقصير في فعلها أو تكرارها سُنة؛ لأنها البديل الوحيد في غياب اللقاح المضياد لهذا الوباء العام في

$$
\text { الوقت الحالي. }
$$

الفرع الثالث: نظافة الطعام والشراب وأثرها في الوقاية من وباء كورونا. حث النبي حث علهها في ذلك:

\section{أولا: غسل اليدين قبل الطعام وبعده وأثره الوقائي.}

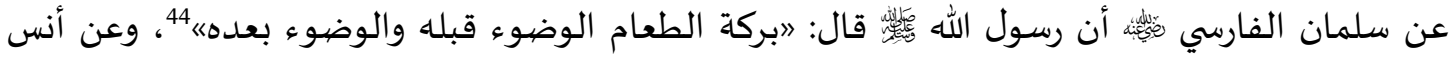

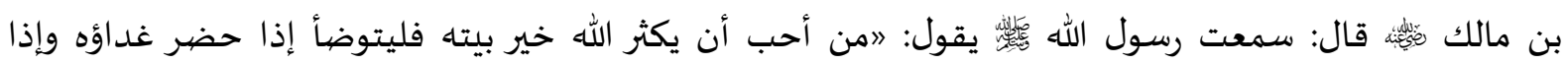

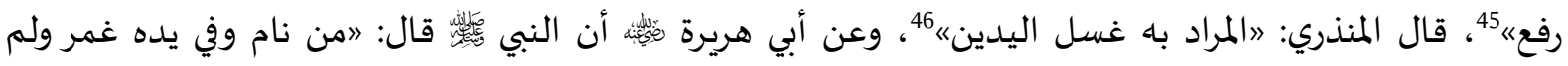
يغسله فأصابه شيء فلا يلومن إلاّ نفسهاه7"؛ ففي حياة الإنسان اليومية كثيراً ما يصافح شخصياً مريضاً أو حاملاً لجراثيم معدية، أو يلمس أشياء ملوثة بجراثيم خطيرة، ثم يجلس لطعامه في غفلة عما تحمله أنامله من جراثيم ملوثة للقمة التي يبتلعها فيصاب بالمرض، وأكثر الأمراض انتشاراً من هذا الطريق: الكوليرا، والتيفوئيد، والزحار؛ هذا وإن الجلد يحتوي على سطحه على أثلام وأخاديد، وإن ما يفرزه من دهن وعرق يساعد على التصاق تلك الجراثيم، وبيوض الطفيليات بالجلد وحفظها بين ثناياه؛ فجاء الهدي النبوي ليحفظ طعامه من الملوثات والأمراض، أما غسل اليدين بعد الطعام، فلأن بقاياه على الأنامل يمكنها أن تتحلل، وتشكل ضمن حرارة الجسم وسطاً ملائماً لتكاثر الجراثيم، وهو ما حذرت منه السنة النبوية.48.

44 ــ رواه أبو داود، في السنن، كتاب الأطعمة، باب في غسل اليد قبل الطعام، 345/3، رقم: 3761، وقال عقبه: لضضعيفه،

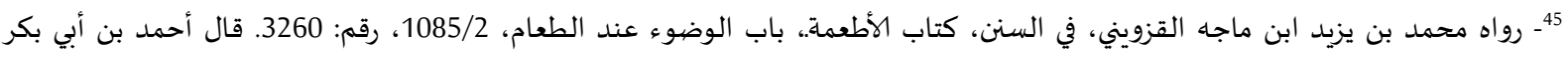

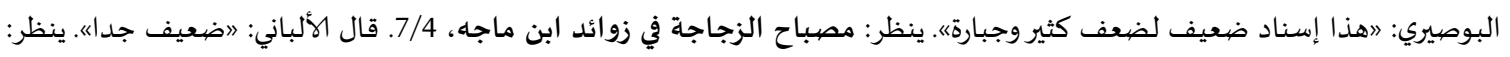

ضعيف الترغيب والترهيب، 46 التيسير بشرح الجامع الصغير، محمد بن تاج العارفين المناوي، 387/2.

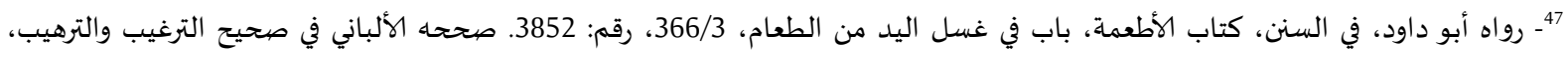


أمر النبي

أسس الوقاية من الأمراض والأوبئة، فعن عمر بن أبي سلامة قِيّئه قال: قال لي النبي

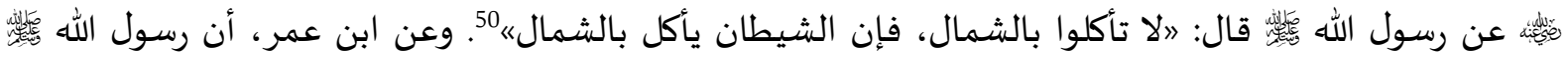
قال: 》إذا أكل أحدكم فليأكل بيمينه، وإذا شرب فليشرب بيمينه فإن الشيطان يأكل بشماله، ويشرب بشماله《ب51.

ثالثا: تخمير آنية الطعام والشراب وأثرها الوقائي.

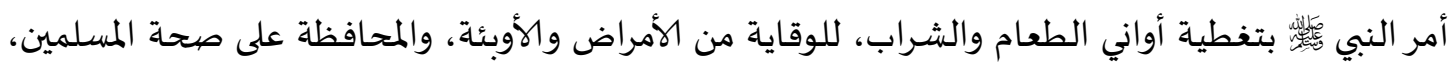

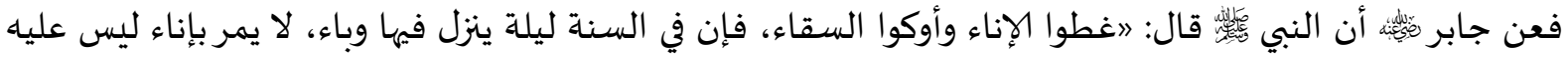
غطاء أو سقاء ليس عليه وكاء إلاّ نزل فياء من ذلك الوباء《52. وقد أثبت الطب الحديث نجاعة ما أخبر به النبي لئب في تغطية أواني الطعام والشراب "لقد أثبت الطب الحديث أن النبي لِّ بين أن الأمراض المعدية تسري في مواسم معينة من السنة، بل إن بعضها يظهر كل عدد معين من السنوات، وحسب نظام دقيق لا يعرف تعليله حتى الآن، من أمثلة ذلك: أن الحصبة وشلل الأطفال يكثر في سبتمبر وأكتوبر والتيفوئيد يكثر في الصيف، أما الكوليرا فإنها تأخذ دورة كل سبع سنوات، والجذري كل ثلاث سنين"53.

$$
\text { رابعا: النهي عن الشرب من في السقاء وأثره الوقائي. }
$$

نهى

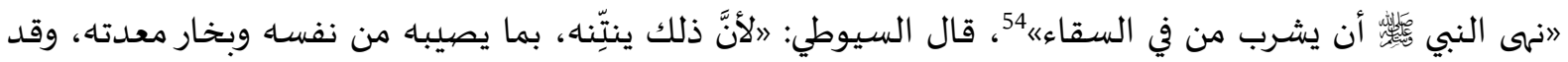
لا تطيب نفس كل أحد بشرب سُؤره فأوجب التنزه من ذلك لئلا يفسده على غيرهـ55.

49-ـ رواه البخاري، في الصحيح، كتاب الأطعمة، باب التيمن في الأكل وغيره، 68/7.

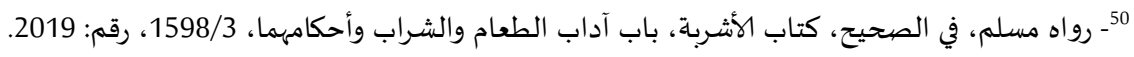

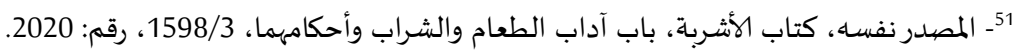

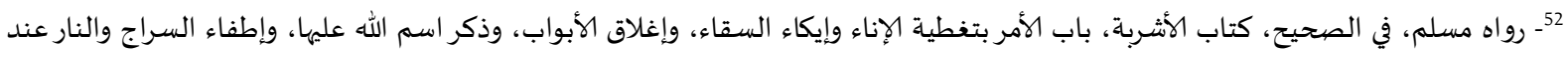

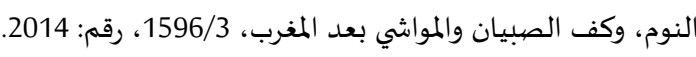

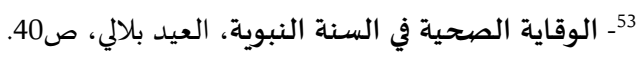

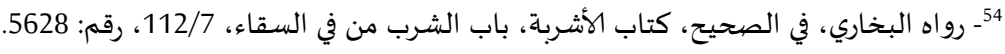




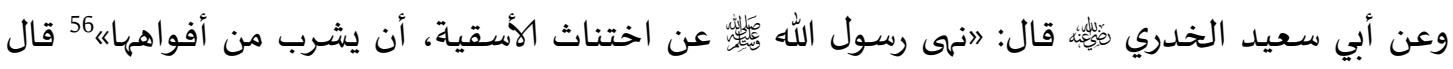

ابن بطال: 》معنى هذا النهى - والله أعلم - على وجه الأدب، لجواز أن تكون في أفواهها حية أو بعض الهوام لا يراها الشارب فيدخل في حلقه، وقد قيل: إن ذلك على سبيل التقذر؛ لأنه يدخلها في فيهی"57.

خامسا: النهي عن التنفس في الطعام والشراب وأثره الوقائي. كان النبي

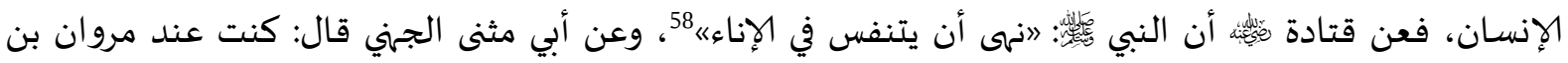

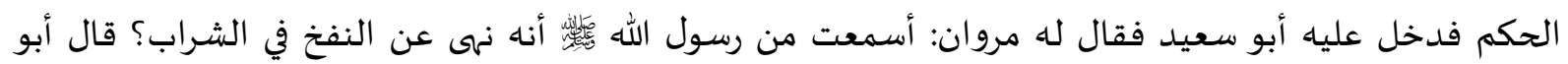

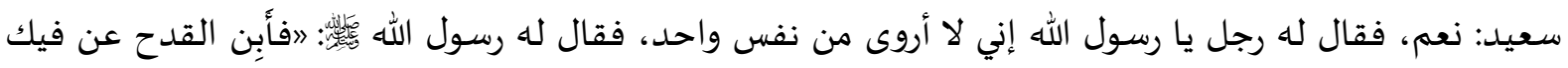
ثم تنفس قال: فإني أرى القذاة فياه قال فأهرقها،59. قال ابن حجر: لوجاء في النهي عن النفخ في الإناء عدة أحاديث وكذا النهي عن التنفس في الإناء؛ لأنه ربما حصل له تغير من النفس، إما لكون المتنفس كان متغير الفم بمأكول مثلا، أو لبعد عهده بالسواك والمضهضية، أو لأن النفس يصعد ببخار المعدة، والنفخ في هذه الأحوال كلها أشد من التنفس"60، وقال ابن القيم: "وأما النفخ في الشراب فإنه يكسبه من فم النافخ رائحة كريهة يعاف لأجلها، ولاسيما إن كان متغير الفم، وبالجملة فأنفاس النافخ تخالطه ولهذا

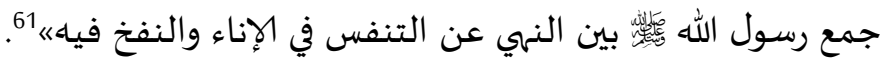
وفي العصر الحديث اكتشف أن "هواء الزفير مفعم بغاز الفحم وفضلات الجسم الطيارة، وما النفخ إلاّ اختلاط لهذه الغازات بالطعام والشراب، ومن ثم إعادتها إلى الجسم عند تناوله لتؤدي فعلها السمي، ومن هنا نفهم

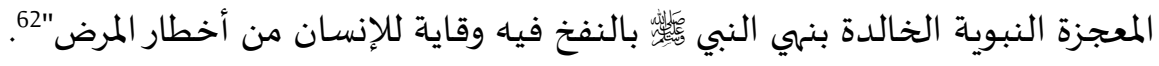

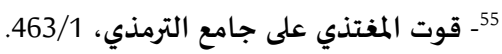

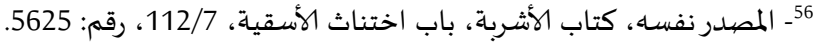

$$
\begin{aligned}
& \text { 57 - شرح صحيح البخاري، لابن بطال، 78/6. }
\end{aligned}
$$

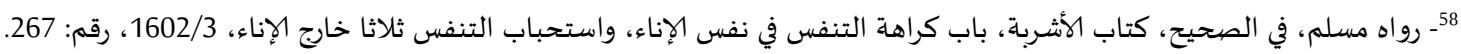

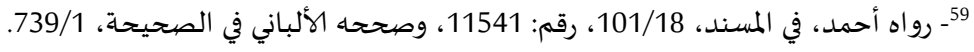

$$
\begin{aligned}
& \text { 60 - 62/10 فتح الباري، } \\
& \text { 61- زاد المعاد في هدي خير العباد، محمد بن أبي بكر ابن قيم الجوزية، 216/4. }
\end{aligned}
$$

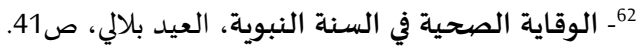


حثت الشريعة الإسلامية قرآنًا وسناةً على التحري في المأكل والمشرب وتجنب المحرمات؛ وهذا لما لها من

أضرار على صحة الإنسان، نذكر منها على سبيل المثال لا الحصر:

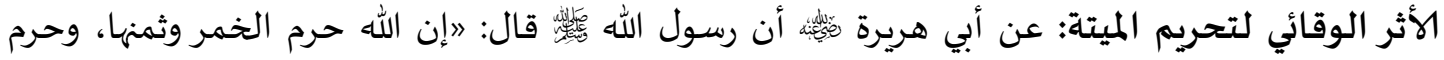

الميتة وثمنها، وحرم الخنزير وثمنهی63، وها هو العلم الحديث يؤيد تحريم أكل الميتة؛ لأن احتباس دم الميتة وسرعة

تفسخ لحمها ملحظان ظاهران فيها يؤكدان التحريم في سائر أنواع الميتة، فكما يحمل الدم غذاء الجسم فإناه يحمل

فضلاته وسموماه، وتقوم كرياته البيضاء ضمن البدن الجي بابتلاع الجراثيم، هذه الأعمال الدفاعية تتوقف تماماً عند فقدان الحياة ويصبح الدم بتركيبه من أصلح الأوساط لنمو الجراثيم وتكاثرها؛ لذا كان استنزاف دم الحيوان حين ذبحاه من الأمور الضرورية من الناحية الطبية، وأن عدم استنزاف دم الحيوان عند ذبحه يجعله غير صالح؛ لأن وجود السائل الزلالي في الأوعية ضمن لحم الذبيحة ييسر للجراثيم الانتشار بسرعة وسط اللحم. والملاحظ أن المجتمعات الآكلة للميتة تفشت فيها الأدواء التي لم يجدوا لها دواءً رغم التطور العلمي، من بينها جائحة كورونا، التي تؤكد الدراسات الأولية أن سبها أكل بعض الحيوانات غير المذبوحة، فيجتمع فيها خبث دمائها ولحمها. كما نلاحظ أن هذه التطبيقات السنية، تعد من أهم الأساليب الوقائية من تفشي الوبئة، وعلى رأسها فيروس كورونا المستجد، الذي ينتقل عبر القنوات الحسية، الأيدي، والأنف، والفم، مما يستلزم وجوبا نظافتها، وحمايتها من كل ما من شأنه أن يتسبب في تلوثها. الأثر الوقائي لتحريم لحم الخنزير: حرمت الشريعة الإسلامية لحم الخنزير لنجاسته، وقد شدد النبي

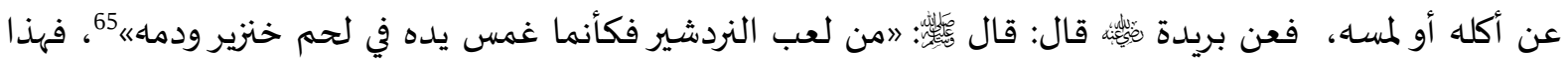
الوعيد لمن لمسـه فما بالك بمن يأكله، وذلك لما له من أضرار كثيرة على جسم الإنسان، وقد أكد الطب الحديث على ذلك؛ حيث توصل إلى "نتائج كثيرة منها: أن الخنزير مرتع لأكثر من 450 مرضا وبائيا، وهو يقوم بدور الوسيط لنقل حوالي 58 منها إلى الإنسان، وتشاركه بعض الحيوانات الأخرى في بقية الأمراض لكنه يبقى المخزن والمصددر الرئيس 63. رواه أبو داود، في السنن، أبواب الإجارة، باب في ثمن الخمر والميتة، 279/3، رقم: 3485. قال الألباني: "صحيحه، ينظر: صحيح الترغيب

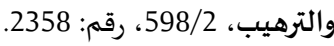

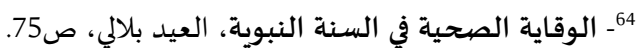

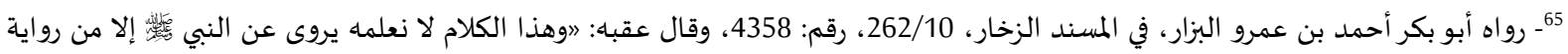

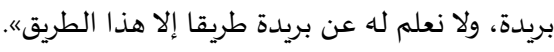


لهذه الأمراض، منها داء الكلب، والحمى اليابانية، والحمى المتوجة، والحميرة الخنزيرية، وإنفلونزا الخنازير إذ يعد مرض فيروسي ينتشر على هيئة وباء يصيب الملايين من الناس ومن مضاعفاته الخطيرة التهاب المخ وتضخم القلب والوهط الدوراني" (66.

الأثر الوقائي لتحريم ذوات الأنياب من السباع والمخالب من الطيور: عن ابن عباس رضي الله عنهما قال: ״نهى رسول الله الأمراض والأوبئة، فقد أثبتت الدراسات العلمية الحديثة أن الإنسان عندما يتناول دهون الحيوانات آكلة العشب تستحلب في أمعائه وتتحول إلى دهون إنسانية، أما عندما يتناول دهون الحيوانات آكلة اللحوم فإن استحلابها عسيرة في أمعائه وإن جزئياته تمتص كما تتسرب في أنسجة الإنسان كدهون حيوانية مؤذية، ويؤكد العلم بعد تطور النظرية الوراثية وتطور الجينات إلى تأثر الآكل بطباع المأكول؛ إذ من المعلوم في أوروبا أن العديد من محترفي الملاكمة والمصارعة يقومون بتناول لحوم الضواري الحيوانات والطيور المفترسة لتزداد

$$
\text { شراستهم وعنفهم وقسوتهم }
$$

الأثر الوقائي في تحريم الخمر: ثبت تحريم الخمر بالقرآن والسنة، وذلك لما لها من أضرار جسيمة على

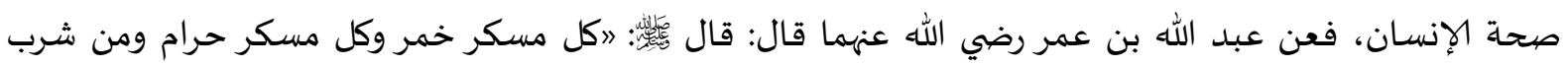
الخمر في الدنيا فمات وهو يدمنها لم يتب لم يشربها في الآخرة؛69، وعن وائل بن حجر الحضرمي أن طارق بن سويد الجعفي سأل النبي داء《70، وقد أثبت الطب الحديث أن الغول (الكحول) هو المادة المؤثرة في الخمر، وسميت كذلك لأنها تغتال العقل ولو صببنا قليلا من الغول على زلال البيض لتخثر حالا وتجمد، ولو وضعنا قطعة من اللحم في الغول لتصلبت وتشمعت وأصبحت كقطعة من الشمع، وهكذا يصنع الغول في خلايا الجسم جميعا عندما يتوالى وصوله إليها، وقد ثبتت سمية الغول إذ يكفي 90 غرام من الغول الإيثيلي لقتل كلب وزنه 15 كيلوغرام كما أنه ليس بالإمكان مطلقا تعيين المقدار من الغول الذي يورث الخطر لمتناوله، كما لا يمكن تحديد المقدار لأقل منه لأن هذا يختلف تماماً من

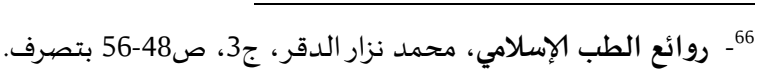

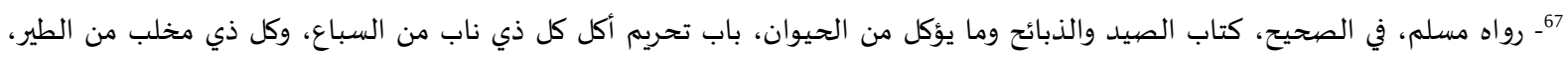
1534/3، رقم: 1934

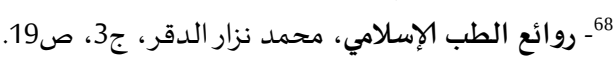

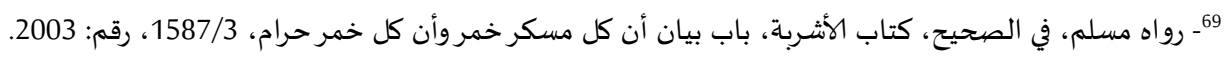

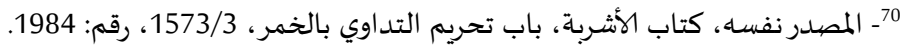


شخص لآخر، كما يتعلق بالعمر والجنس والعرق ونوعية الطعام وطراز الحياة وحالة الشخص من جوع أو شبع وغير

ومنه فالمطاعم والمشارب الخبيثة والمحرمة لها أثر مباشر في تفشي وباء كورونا المستجد؛ لأن دورها في

إضعاف مناعة الإنسان لا تخفى على المختصين، الذين صرحوا بأن أكثر المرضى عرضية لمضياعفات فيروس كورونا هم المصابون بالأمراض المزمنة الناتجة عن النظام الغذائي المحرم.

سـابعا: الحكم المستخلصية.

من خلال التدابير الوقائية الصحية المتخذة للوقاية من وباء كورونا المستجد، والدعوة إلى التحذير من بعض المآكل والمشارب لعظم ضررها على الإنسان ونقلها المباشر للأوبئة، نجد سبق الشريعة الإسلامية إلى وضع قواعد الوقاية من الأوبئة المنقولة من المآكل والمشارب الخبيثة.

فعلى المسلم الحرص على تطيبب مأكله ومشربه، واتباع آداب الطعام والشراب التي حث عليها النبي

للسلامة من الأوبئة المنقولة عن طريقها؛ منها عدم التنفس في الطعام لتسببه في نقل الأمراض التنفسية، من بينها وباء كورونا المستجدد.

المطلب الثاني: التطبيقات الاجتماعية الوقائية من الأوبئة من خلال السيرة النبوية وأحكامها. سلك النبي لِك عدة سبل للوقاية من الأوبئة، أثبتت التطبيقات المعاصرة نجاعتها في التصدي للأوبئة الفتاكة، فسبقت بذلك السنة النتائج التي توصل إلهها العلم الحديث، بعد معاناة البشرية زمنا طويلا، وبعد تكبد خسائر بشرية فادحة، ومن بين الحلول الوقائية من الأوبئة في السيرة النبوية على المستوى الاجتماعي نذكر:

\section{الفرع الأول: عزل الموبوء وأثره في الوقاية من الأوبئة.}

أول إجراء نهجه النبي العدوى، ومن الأحاديث الدالة على ذلك:

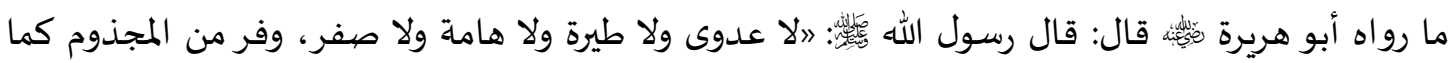

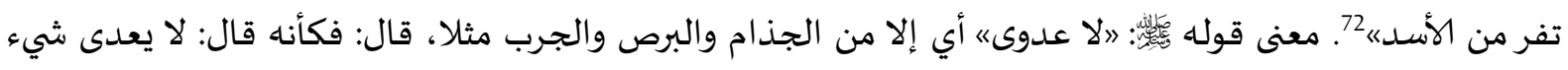
إلــاية الصحية في السنة النبوية، العيد بلالي، ص86. 
شيئا إلا ما تقدم تبيني له أن فيه العدوى، أما الأمر بالفرار من المجذوم ليس من باب العدوى في شيء، بل هو لأمر طبيعي، وهو انتقال الداء من جسد لجسـ، بواسطة الملامسة، والمخالطة وشم الرائحة؛ ولذلك يقع في كثير من الأمراض في العادة انتقال الداء من المريض إلى الصحيح بكثرة المخالطة، قال ابن قتيبة: المجذوم تشتد رائحته حتى

وعن أبي هريرة قِئِّ: قال: قال رسول الله

بال الإبل تكون في الرمل كأنها الظباء فيجيء البعير الأجرب فيها فيجربها كلها، قال: 》فمن أعدى الأول«74.

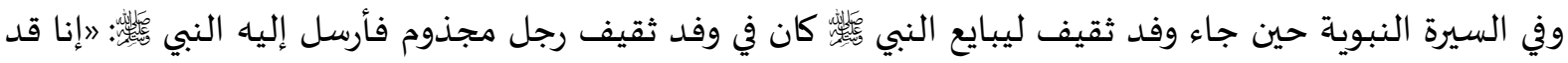
بايعناك فارجع«"75. الشـاهد، هو أن النبي الناس، وعدم مصافحته، خشية انتقال العدوى؛ وهو منهج حكيم مناه وقد سار على هذا النهج الصحابة الكرام رضوان الله عليهم؛ فعن ابن أبي مليكة؛ أن عمر بن الخطاب نِّئن: مر بامرأة مجذومة، وهي تطوف بالبيت، فقال لها: يا أمة الله لا تؤذي الناس، لو جلست في بيتك. فجلست، فمر بها رجل بعد ذلك فقال لها: إن الذي كان قد نهاك، قد مات، فاخرجي. فقالت: ما كنت لأطيعه حيا، وأعصيه ميتاج7. الشاهد من الرواية أنه يمنع المجذوم من المسجد والدخول بين الناس واختلاطه بهمج.77. فكان من أثر ذلك أن أول مستشفى أنشئ للمجذومين في الإسلام، كان على يد الوليد بن عبد الملك سنة 88هـ، في حين لم تعرف أوروبا هذا النوع من المستشفيات قبل القرن الثاني عشر حين نقلها الصليبيون عن المسلمين

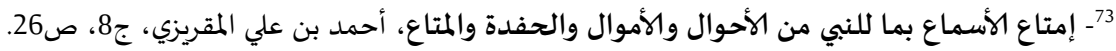

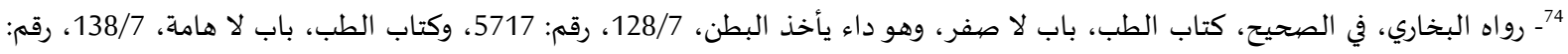
5770، باب لا عدوى، 139/7، رقم:

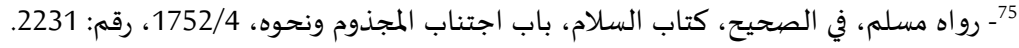

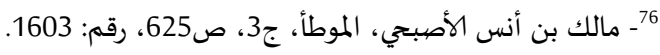

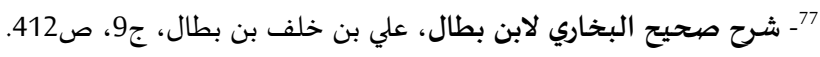

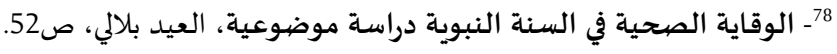


عزل الموبوء الذي دعا إليه الهدي النبوي، تجسد عمليا عن طريق التدابير الوقائية المعاصرة الداعية إلى التباعد الاجتماعي وعزل المريض خشية نقله الوباء للأصحاء وهذا بعدم مصافحته، وتقبيله، والأكل معه. فعلى المسلم مريضا كان أم صحيحا الامتثال للأمر النبوي والحرص على التباعد الاجتماعي، ويتأكد ذلك في حق المريض الذي تظهر عليه أعراض كورونا الذي يجب أن يمتنع عن مخالطة الناس خاصة في العبادات التي يغلب عليها التجمع، كالصلاة والحج، بل إنه يأثم عند تعمده مخالطة الناس وإخفاء مرضه.

\section{الفرع الثاني: حَجْرُ الموبوء وأثره في الوقاية من الأوبئة.}

من السبل الاجتماعية الوقائية التي سلكها النبي بَّلة للتصدي للأوبئة والجوائح، عزل المنطقة التي ظهر فيها الوباء وحجرها عن باقي المناطق؛ لئلا ينتقل الوباء إلها وهذا بمنع الدخول إليها، أو الخروج منها:

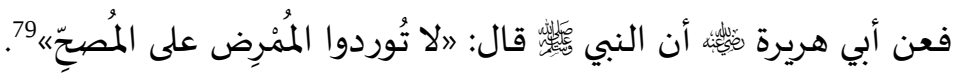

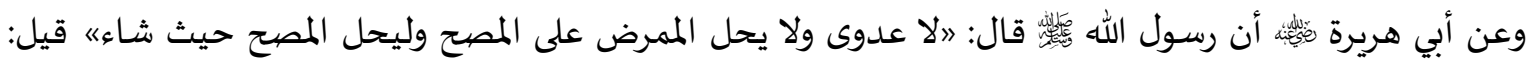
ما بال ذلك يا رسول الله؟ قال: 》 إنه أذى «80. وعن عائشة رضي الله عنها قالت: 》لا تفنى أمتي إلاّ بالطعن والطاعون قلت: يا رسول الله هذا الطعن قد عرفناه فما الطاعون؟ قال: غدة كغدة البعير، المقيم بها كالشهيد، والفار منها كالفار من الزحف«ه.

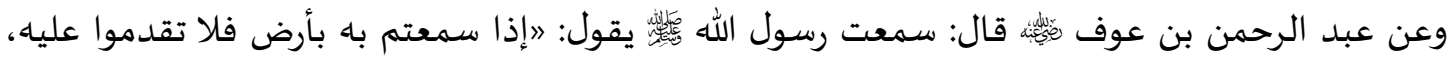
وإذا وقع بأرض وأنتم بها فلا تخرجوا فرارا منه يعني الطاعون《82، قال الخطابي: "في قوله لا تقدموا عليه إثبات الحذر والنهي عن التعرض للتلف، وفي قوله لا تخرجوا فرارا منه، إثبات التوكل والتسليم لأمر الله وقضائه فأحد

$$
\text { الأمرين تأديب وتعليم، والآخر تفويض وتسليم³. }
$$

79- رواه البخاري، في الصحيح، كتاب الطب، باب لا عدوى، 139/7، رقم:

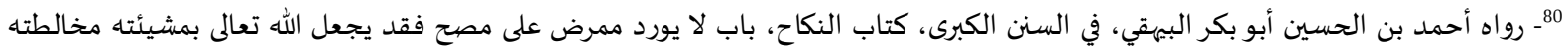

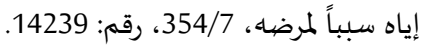

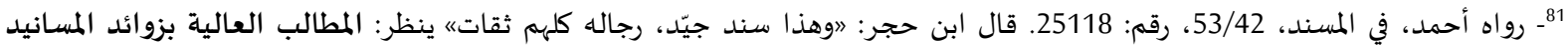

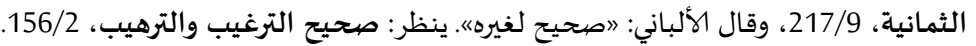

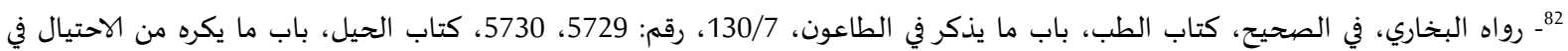
الفرار من الطاعون، 26/9، رقم: 6973. 83 - معالم السنن، حمد بن محمد الخطابي، 299/1. 


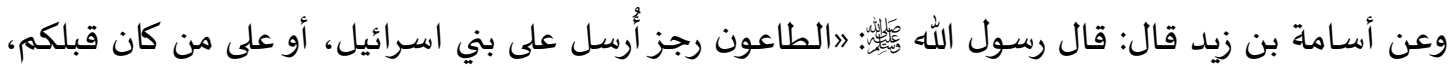
فإذا سمعتم باه بأرض فلا تقدموا عليه، وإذا وقع بأرض، وأنتم بها، فلا تخرجوا فراراً مناهـ84. وفي رواية: 》إن هذا الوجع، أو السقم رجز، عُدِّب بهه بعض الأمم قبلكم، ثم بقي بعد بالأرض، فيذهب المرّة،

ويأتي الأخرى، فمن سمع به بأرض، فلا يَقْدَمَنّ عليه، ومن وقع بأرض، وهو بها فلا يخرجنه الفرار منهـا85. قال ابن عبد البرّ - رحماه الله -: "اؤما نهيه

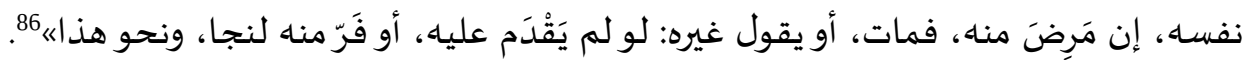

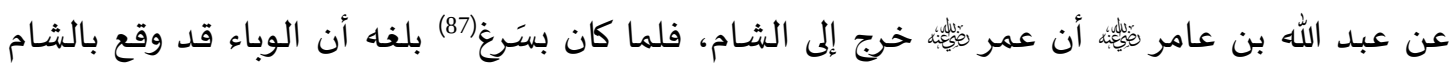

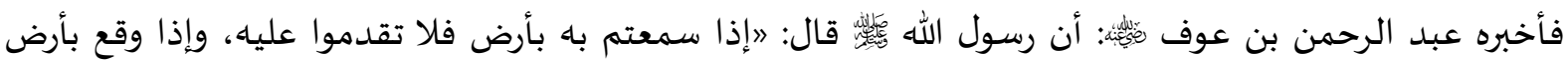
وأنتم بها، فلا تخرجوا فرارا منهه، قال: فحمد الله عمر ثم انصرف 88.

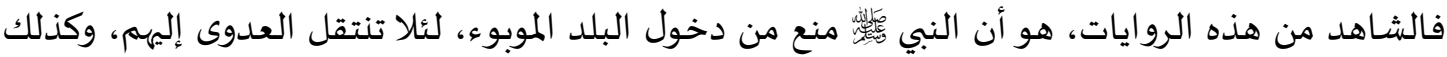
منع الأشخاص الموجودين في البلد الموبوء من الخروج منه حتى وإن لم يكونوا موبوئين، لحكمة عظيمة بينها الطب الحديث؛ إذ أن الشخص السليم في منطقة الوباء قد يكون حاملا للمكروب، ولكن لا تبدو عليه أعراض المرض، لقوة المناعة عنده، أو أن أعراض المرض كامنة في جسمه لا تظهر إلا بعد مدة ويبدو هذا الشخص وافر الصحة سليم الجسم ومع ذلك فهو ينقل المرض إلى غيره من الأصحاء؛ لذلك جاء منع النبي ينتقلوا منها تشريعا رائعا ومعجزة علمية ظهرت حقيقتها بعد مضي أربعة عشر قرنا من الزمان.89.

84

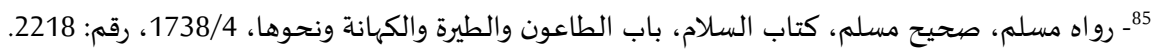

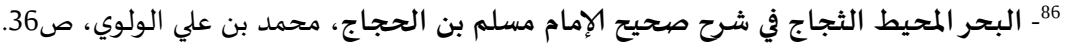

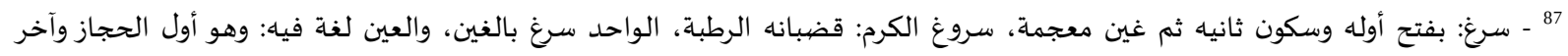

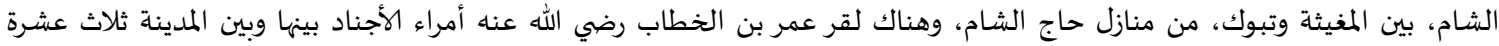

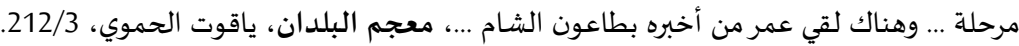

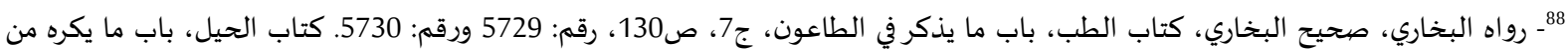

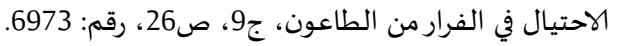

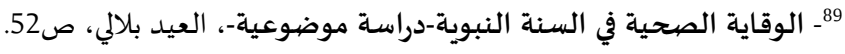


حجر المناطق الموبوءة بمنع الدخول إلها أو الخروج منها، من السبل التي دعت إلها السنة النبوية، وجسدها الصحابة عمليا حين حلول الطاعون في البلاد المفتوحة بالشام، وهو ما أسهم في حصر المناطق الموبوءة وعدم تعديها للبلاد الإسلامية السالمة منه.

فوجب على المسلم امتثال قواعد الحجر الصي، وعدم خرقها بوصفه أمرا شرعيا قبل أن يكون من قواعد الصحية التي وضعت من قبل السلطات، ويَجعل ذلك تعبدا لله تعالى حتى ينحصر الوباء ويقل المصابون، وقد ثبتت نجاعة الحجر الصحي في محاربة كورونا المستجد قبل ايجاد اللقاحات، واستفاد المسلمون بما كانت الشريعة الإسلامية سباقة له في وضع قواعد الحجر.

الفرع الثالث: نظافة البيئة وأثرها في الوقاية من الأوبئة.

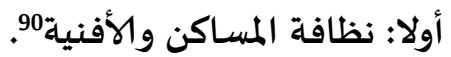
اعتنت السنة النبوية عناية فائقة بنظافة المساكن والأفنية، وهذا للوقاية من الأمراض والأسقام التي

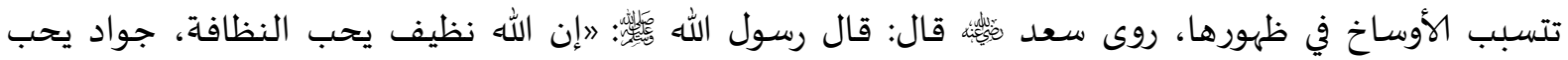
الجود، كريم يحب الكرم، طيب يحب الطيب فنظفوا أفنيتكم ولا تشبهوا باليهود تجمع الأكباء91 في دورهاء92، قال الأميز الصنعاني: 》عائد إلى التنظيف فإنهم أوسخ خلق الله أبدانًا وثيابًا ولذا تجد منهم زهومة مكروهة ومنازلهم معدن الأوساخ والأقذار بحيث تدرك لأثارهم رائحة،

ثانيا: الحرص على نظافة المساجد. المساجد بيوت الله، وملتقى المسلمين للعبادة؛ لذلك ندب النبي لئل إلى العناية بها والمحافظة على نظافها، للوقاية من الأمراض التي تنجر عن انتشار الأوساخ والرجس فيها، ومن جملة توجيهاته ئلئي في ذلك:

90ـ الأفنية: جمع فناء بكسر الفاء المتسع أمام الدار. ينظر: التنوير شرح الجامع الصغير، محمد بن إسماعيل الأمير الصنعاني، 311/3.

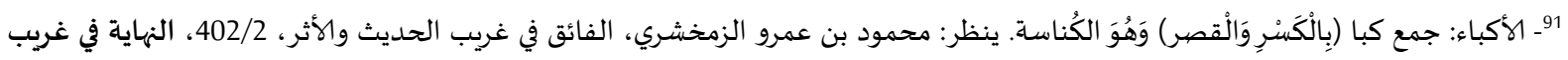

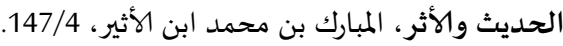

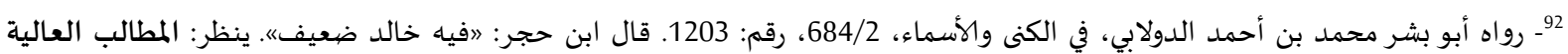

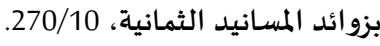

939 التنوير شرح الجامع الصغير، محمد بن إسماعيل الأمير الصنعاني، 311/3. 


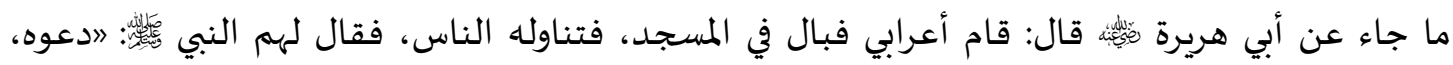
واهريقوا على بوله سجلاً من ماء، أو ذنوبا من ماء فإنما بعثتم ميسرين ولم تبعثوا معسرين«94. الشاهد من الحديث أن النبي فياه النجاسة فتكثر الأمراض والأوبئة.

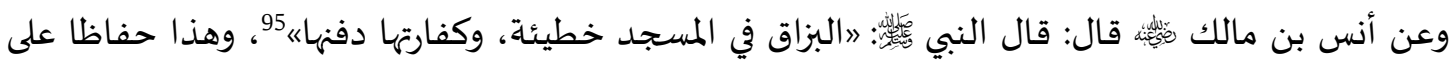
نظافة المسجد وعدم تلويثه بالأوساخ، والتي تنجر عنها انتشار الأمراض؛ فاعتبرها النبي كفارتها هو تنظيفها وهذا بدفنها. وكانت في عهده عليها، وعلة الدعوة للعناية بنظافة المساجد أهها موطن توافد الناس فكان من الأسلم تطهيرها كي تزول مسببات الأمراض والعدوى.

ثالثا: الحرص على نظافة الأماكن العامة والطرقات من هدياه والأوبئة ومما ورد في ذلك من أحاديث:

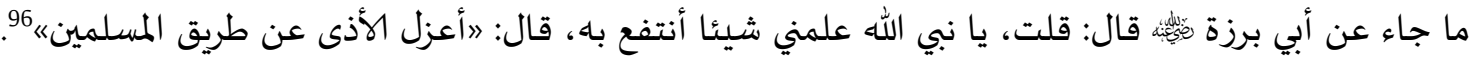

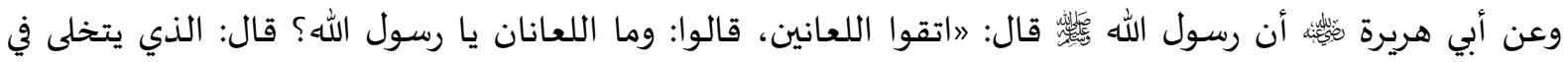

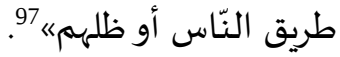

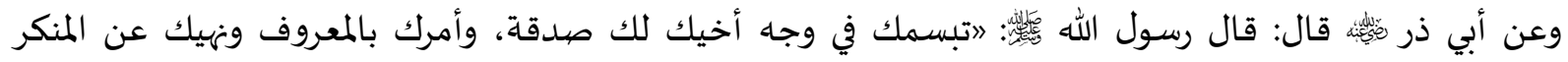
صدقة، وإرشادك الرجل في أرض الضلال لك صدقة، وبصرك للرجل الرديء البصر لك صدقة، وإماطتك الحجر والشوكة والعظم عن الطريق صدقة، وإفراغك من دلوك في دلو أخيك لك صدقةهُ98.

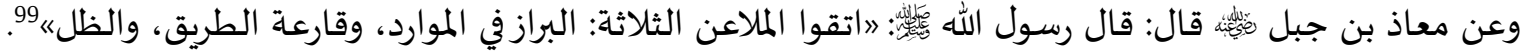
94-ـ رواه البخاري، في الصحيح، كتاب الوضوء، باب صب الماء على البول في المسجد، 54/1، رقم: 220.

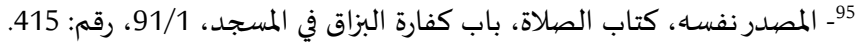

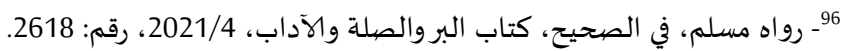

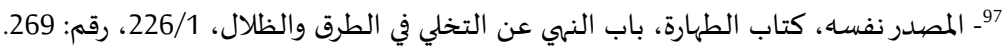

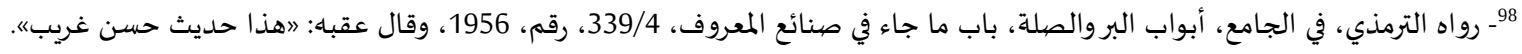


رابعا: الحرص على نظافة موارد المياه.

تلوث مصادر المياه من أخطر ما تواجهه البيئة في العصر الحديث، والذي ينجر عنه ظهور أمراض وأوبئة كثيرة منها على سبيل المثال لا الحصر: الكوليرا، التيفوئيد، الدودة الكبدية، البلهارسيا وغيرها؛ والمتتبع للسنة والسيرة العطرة يجد أن النبي

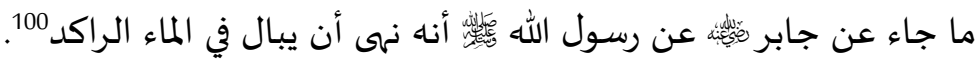

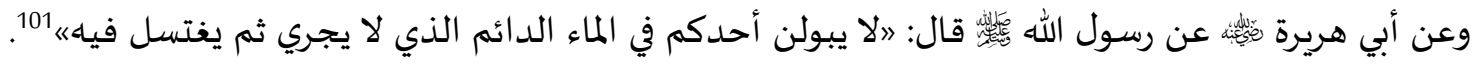
ففي هذه الأحاديث دعوة لفصل مجاري المياه القذرة عن المياه الصالحة للشرب؛ لأنه من مسببات النقل

$$
\text { السريع للجراثيم وتكاثرها، وهو المعمول به في العصر الحديث في تشييد المدن العامرة. }
$$

\section{خامسا: الحكم المستخلصية.}

من لوازم حجر المرضى وعزل المناطق الموبوءة، الحرص على نظافة المساكن والمساجد والأماكن العامة، لما

فيها من الاختلاط والتجمع المؤدي إلى تفشي الأوبئة الفتاكة، التي من طبيعتها الانتشاروسرعة الانتقال بين الناس. فوجب على المسلم الحرص على نظافته أينما حل وارتحل للتقليل من نشر الوباء الذي يستشري بفعل كثرة النجاسات بين الناس، وإن تطلب الأمر الغلق العام أو الجزئي للأماكن العامة كالمحلات، والمساجد حرصا على نظافتها فعلى المسلم الاستجابة للتعليمات الصحية الموافقة لمقاصد الشرع الحكيم.

الخاتمة:

بعد جمع الروايات التي رأينا أهها تناسب هذا الموضوع، من مصادر السنة المختلفة وعلى رأسها الجامع الصحيح للإمام البخاري، وصحيح الإمام مسلم، والنظر في مقاصدها، واستنباط علاقهها بالأوبئة بشكل عام، وبجائحة كورونا بخاصاة، باتباعنا المنهجين الاستقرائي والتحليلي، وبعد التأكيد على أن السنة النبوية استوفت الكلام عن كل ما يهم المسلمي؛ فبينت لهم ما فياه مصالحهم في الدنيا والآخرة، ونهته عن كل ما فيا مضارهم ومفسدتهم في الدين، والنفس، والعرض، والمال، والنسل، والعقل، كما بينت لهم السبل الواقية من الأوبئة، ومن

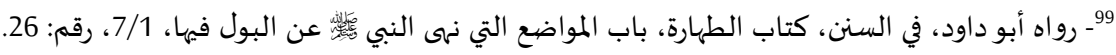

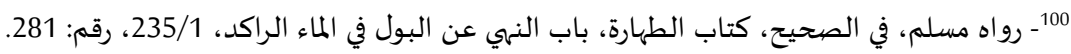

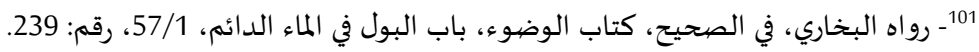


غيرها مما قد يلحقهم من شرورومضرات، لنصل بعد النظر في هذه المسألة، وتتبعها فيما ذكرناه من أحاديث نبوية، إلى القول بأن الشريعة الإسلامية كان لها فضل السبق إلى الكلام عن هذه التطبيقات الوقائية، والإجراءات العلاجياة، وأهها السبَّاقة إلى بيان سبل الوقاية التعبدية والاتششفائية من الأوبئة، وقد ثبتت فعاليتها في واقع الناس قديما وحديثا؛ فما ظهر مؤخرا أثناء جائحة كورونا، ولجوء البشرية مسلمها وكافرها، إلى هذه التطبيقات، لخير دليل على الإعجاز العلمي والطبي للسنة النبوية؛ كما اتضح لمسلمي البشرية وكافريها، ومؤمنيها، ومنكريها، أن سبب وقوع الجوائح والأوبئة، إنما هو بما كسبت أيدي الناس؛ الإفساد في البروالبحر، ومن الآثام، والمحرمات، وترك الطاعات، كما ظهر لمسلميهم بخاصة، أثر العبادة بامتثال الأوامر، واجتناب النواهي، في الوقاية من الأوبئة، كما ظهر لهم ما للطهارة، وفق الشريعة الإسلامية وضوابطها من الحدث والخبث، من فعالية لا ريب فيها، في الوقاية المستمرة من الأوبئة؛ وذلك بللمواظبة على النظافة الحسية والمعنوية، وتطييب المأكل والمشرب وفق الضيوابط الإسلامية، ولا يفوتنا التأكيد على أسبقية السيرة النبوية إلى الكلام عن عزل وحجر الموبوء عند انعدام الأدوية واللقاحات؛ لأنه سبب في منع انتقال العدوى، وهو الإجراء الذي يدعو إليه العلماء، ويؤكد عليه الأطباء ومنظمة الصحة العالمية؛ ما يثبت أن الشريعة الإسلامية متميزة بأحكام خاصة في حال وقوع الوباء العام، ويدل قطعا على صلاحيتها لكل زمان ومكان، ويؤكد على تقديمها لمصالح العباد ودريها للمفاسد عنهم.

وفي ختام هذا البحث، نوصي أنفسنا والمسلمين جميعا بتقوى الله هَّيَلْ لرفع البلاء والوباء، وندعو المختصين

للجمع بين الدراسات الشرعية والطبية، وذلك لتوافق العلم مع الشرع، حتى يتم الوصول إلى الحلول الناجعة عند وقوع الأوبئة، كما يستحسن تسليط الضوء على مقاصد العبادات الشرعية، وبيان دورها في الوقاية من الأوبئة عموما ومن وباء كورونا خصوصا، مع دراسة عللها لما فياء من زيادة اليقين بصحة الشريعة الإسلامية وصلاحيتها لكل زمان ومكان، كما ندعو إلى إنجاز دراسات تحليلية حول السنة قصد استنباط واستخراج حِكَمِها وفوائدها. لتقديم الحلول للمعضلات والنوازل المعاصرة. 
أنيس الساري في تخريج وتحقيق الأحاديث التي ذكرها الحافظ ابن حجر في فتح الباري، الكويتي، نبيل بن منصور

$$
\begin{aligned}
& \text { أبو حذيفة، (ط 1، بيروت: مؤسسة السماحة ومؤسسة الريان، 1426هـ-2005م). } \\
& \text { الإعجاز العلمي في السنة النبوية، زغلول النجار، (ط 6، مصر: مطبعة النهضة، 2006م). } \\
& \text { الإعجاز العلمي في السنة النبوية، صالح رضا، (ط1، الرياض: مكتبة العبيكان، 2001م). }
\end{aligned}
$$

إمتاع الأسماع بما للنبي من الأحوال والأموال والحفدة والمتاع، المقريزي، أحمد بن علي، تحقيق: محمد عبد الحميد

$$
\text { النميسي، (ط 1، بيروت: دار الكتب العلمية، 1420هـ-1999م). }
$$

البحر المحيط الثجاج في شرح صحيح الإمام مسلم بن الحجاج، الولوي، محمد بن علي، (ط 1، د.م، دار ابن

$$
\text { الجوزي، 1426هـ-1436هـ). }
$$

البداية والنهاية، الدمشقي، ابن كثير إسماعيل بن عمر (د.ط، د.م، دار الفكر، 1407هـ-1986م).

$$
\text { تاج العروس من جواهر القاموس، الزبيدي، محمد بن محمد مرتضى، (د.ط، د.م، دار الهداية، د.ت). }
$$

تفسير القرآن العظيم، الدمشقي، ابن كثير إسماعيل بن عمر، تحقيق: محمد حسين شمس الدين، (ط 1، بيروت:

$$
\text { دار الكتب العلمياة، منشورات محمد علي بيضون، 1419هـ). }
$$

التمهيد لما في الموطأ من المعاني والأسانيد، القرطبي، يوسف بن عبد الله بن عبد البر، تحقيق: مصطفى بن أحمد العلوي، محمد عبد الكبير البكري، (د.ط، المغرب: وزارة عموم الأوقاف والشؤون الإسلامياة، 1387ه).

التنوير شرح الجامع الصغير، الصنعاني، محمد بن إسماعيل الأمير، تحقيق: محمد إسحاق محمد إبراهيم، (ط 1،

$$
\text { الرياض: مكتبة السلام، 1432هـ/2011م). }
$$

التيسير بشرح الجامع الصغير، المناوي، محمد بن تاج العارفين، (ط 3، الرياض: مكتبة الإمام الشافعي،

$$
\text { 1408 1488/مه (1988) }
$$

الجامع، الترمذي، محمد بن عيسى، تحقيق: أحمد محمد شاكر وآخرون، (ط 2، مصر: شركة مكتبة ومطبعة

$$
\text { مصطفى البابي الحلبي، 1395هـ/1975م). }
$$

جامع البيان عن تأويل آي القرآن، الطبري، محمد بن جرير، تحقيق: د. عبد الله بن عبد المحسن التركي، (ط 1،

$$
\text { القاهرة: هجر للطباعة والنشر والتوزيع، } 1422 \text { هـ/ } 2001 \text { م) }
$$


الجامع المسند الصحيح المختصر من أمور رسول الله محمد زهير بن ناصر الناصر، (ط 1، د.م، دار طوق النجاة، 1422هـ).

روائع الطب الإسلامي، محمد نزار الدقر، (موقع موسوعة الإعجاز العلمي في القرآن والسنة www.55a.net زاد المعاد في هدي خير العباد، ابن قيم الجوزية، محمد بن أبي بكر، (ط 27، بيروت: مؤسسة الرسالة، الكويت: مكتبة المنار الإسلامية، 1415هـ-1994م).

السراج المنير في ترتيب أحاديث صحيح الجامع الصغير، السيوطي، عبد الرحمن بن أبي بكر جلال الدين، تحقيق: عصام موسى هادي، (ط 3، د.م، دار الصديق، 1430هـ/2009م).

سلسلة الأحاديث الصحيحة وشيء من فقها وفوائدها، الألباني، محمد ناصر الدين (ط1، الرياض: مكتبة المعارف،

$$
\text { 1422 هـ-2002م). }
$$

السنن، السجستاني، سليمان بن الأشعث أبو داود، تحقيق: محمد محيي الدين عبد الحميد، (د.ط، بيروت: المكتبة

$$
\text { العصرية، د.ت). }
$$

السنن، القزويني، محمد بن يزيد ابن ماجاه، تحقيق: محمد فؤاد عبد الباقي، (د.ط، د.م، دار إحياء الكتب العربية،

$$
\text { فيصل عيسى البابي الحلبي، د.ت). }
$$

السنن الكبرى، البيهق، أحمد بن الحسين أبو بكر، تحقيق: محمد عبد القادر عطا، (ط 3، بيروت: دار الكتب

$$
\text { العلمياة، 1424هـ/2003م). }
$$

سير أعلام النبلاء، الذهبي، محمد بن أحمد شمس الدين، تحقيق: شعيب الأرناؤوط، (ط 3، د.م، مؤسسة

$$
\text { الرسالة، 1405هـ-1985م). }
$$

شرح صحيح البخاري، ابن بطال، علي بن خلف، تحقيق: ياسر بن إبراهيم، (ط 2، الرياض: مكتبة الرشد،

$$
\text { 2003/هـ 1423 }
$$

الصحاح تاج اللغة وصحاح العربية، الجوهري، إسماعيل بن حماد، تحقيق: أحمد عبد الغفور عطار، (ط 4،

$$
\text { بيروت: دار العلم للملايين، 1407هـ/1987م). }
$$

صحيح ابن حبان بترتيب ابن بلبان، محمد بن حبان، تحقيق: شعيب الأرنؤوط، (ط 2، بيروت: مؤسسة الرسالة،

$$
\text { 1993/ه1414 1414 }
$$


صحيح الترغيب والترهيب، الألباني، محمد ناصر الدين (ط 1، السعودية: مكتبة المعارف للنشر والتوزيع، 1421هـ$\cdot(2000$

صحيح الجامع الصغير وزياداته، الألباني، محمد ناصر الدين، المكتب الإسلامي (د.ط، د.م، د.ن، د.ت). ضعيف الترغيب والترهيب، الألباني، محمد ناصر الدين (ط 1، الرياض: مكتبة المعارف للنشر والتوزيع، 1421 هـ/2000م)

الفائق في غريب الحديث والأثر، الزمخشري، محمود بن عمرو، تحقيق: علي محمد البجاوي، (ط 2، لبنان: دار

$$
\text { المعرفة، د.ت). }
$$

فتح الباري شرح صحيح البخاري، العسقلاني، أحمد بن علي بن حجر، تحقيق: محمد فؤاد عبد الباقي، (د.ط،

$$
\text { بيروت: دار المعرفة، 1379هـ). }
$$

قوت المغتذي على جامع الترمذي، السيوطي، جلال الدين، تحقيق: ناصر بن محمد بن حامد الغريبي، (د.ط، مكة

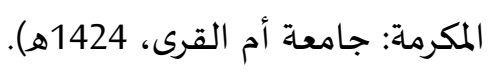

الكنى والسمماء، الدولابي، محمد بن أحمد أبو بشر، تحقيق: أبو قتيبة نظر محمد الفاريابي، (ط1، بيروت: دار ابن

$$
\text { حزم، 1421هـ/2000م). }
$$

$$
\text { لسان العرب، ابن منظور، محمد بن مكرم، (ط 3، بيروت: دار صادر، 1414هـ). }
$$

مجمع الزوائد ومنبع الفوائد، الهيثمي، علي بن أبي بكر نور الدين، تحقيق: حسام الدين القدسي، (د.ط، القاهرة: مكتبة القدسي، 1414هـ/ 1994م).

مجمل اللغة، القزويني، أحمد بن فارس، تحقيق: زهير عبد المحسن سلطان، (ط 2، بيروت: مؤسسة الرسالة، 1406هـ-1986م)

مختار الصحاح، الحنفي، محمد بن أبي بكر زين الدين، تحقيق: يوسف الشيخ محمد، (ط 5، بيروت: المكتبة العصرية، الدار النموذجية، 1420هـ-1999م).

مرقاة المفاتيح شرح مشكاة المصابيح، الهروي، علي بن محمد، (ط 1، لبنان: د.ن، 1422هـ-2002م).

المستخرج من الأحاديث المختارة مما لم يخرجه البخاري ومسلم في صحيحهما، المقدسي، محمد بن عبد الواحد ضياء الدين، تحقيق: ابن دهيش، عبد الملك بن عبد الله، (ط 3، بيروت: دار خضر للطباعة والنشر، 
المستدرك على الصحيحين، النيسابوري، الحاكم محمد بن عبد الله، تحقيق: مصطفى عبد القادر عطا، (ط 1،

$$
\text { بيروت: دار الكتب العلمية، 1411هـ-1990م). }
$$

المسند، الشيباني، أحمد بن محمد بن حنبل، تحقيق: شعيب الأرنؤوط، (ط 1، د.م، مؤسسة الرسالة، 1421هـ/

$$
\text { .) } 2001
$$

المسند الزخار، البزار، أحمد بن عمرو أبو بكر، تحقيق: عادل بن سعد، (ط 1، المدينة المنورة: مكتبة العلوم والحكم، 2009م). المسند الصحيح المختصر بنقل العدل عن العدل إلى رسول الله هئلة، النيسابوري، مسلم

$$
\text { بن الحجاج، تحقيق: محمد فؤاد عبد الباقي، (د.ط، بيروت: دار إحياء التراث العربي، د.ت). }
$$

مصباح الزجاجة في زوائد ابن ماجه، البوصيري، أحمد بن أبي بكر، تحقيق: محمد المنتقى الكشناوي، (ط 2،

$$
\text { بيروت: دار العربية، 1403هـ). }
$$

المطالب العالية بزوائد المسانيد الثمانية، العسقلاني، أحمد بن علي بن حجر، تحقيق: سعد بن ناصر بن عبد

$$
\text { العزيز الشثري، (ط 1، د.م، دار العاصمة للنشر، 1419هـ/1998م). }
$$

معالم السنن، الخطابي، حمد بن محمد، (ط 1، حلب: المطبعة العلمية، 1351هـ/1932م). المعجم، ابن الأعرابي البصري، أبو سعيد، تحقيق: عبد المحسن بن إبراهيم بن أحمد الحسيني، (ط 1، السعودية: دار ابن

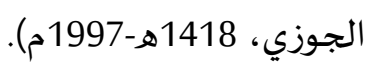

المعجم الأوسط، الطبراني، سليمان بن أحمد أبو القاسم، تحقيق: طارق بن عوض الله بن محمد وعبد المحسن بن

$$
\text { إبراهيم الحسيني، (د.ط، القاهرة: دار الحرمين، د.ت). }
$$

معجم مقاييس اللغة، القزويني، أحمد بن فارس، تحقيق: عبد السلام محمد هارون، (د.ط، د.م، دار الفكر، 1399هـ-1979م)

معجم اللغة العربية المعاصرة، أحمد مختار عبد الحميد عمر، (ط 1، د.م، عالم الكتب، 1429هـ/2008م). معجم لغة الفقهاء، محمد رواس قلعجي وحامد صادق قنيبي، (ط 2، دار النفائس للطباعة والنشر والتوزيع، 1408هـ 1988مـ

المعجم الوسيط، مجمع اللغة العربية (د.ط، القاهرة: دار الدعوة، د.ت). المنهاج شرح صحيح مسلم بن الحجاج، النووي، يحيى بن شرف، (ط 2، بيروت: دار إحياء التراث العببي، 1392ه). 
الموطأ، الأصبحي، مالك بن أنس، تحقيق: محمد مصطفى الأعظمي، (ط 1، الإمارات: مؤسسة زايد بن سلطان آل نهيان للأعمال الخيرية والإنسانية، 1425هـ-2004م).

الهاية في غريب الحديث والأثر، ابن الأثير، المبارك بن محمد، تحقيق: طاهر أحمد الزاوي، (د.ط، بيروت: المكتبة

$$
\text { العلمياة، 1399هـ/1979م). }
$$

الوقاية الصحية في السنة النبوية دراسة موضوعية، بلالي العيد، ماجستير في الكتاب والسنة، (الجزائر: كلية أصول

$$
\text { الدين، جامعة الجزائر01، 2010-2011م). }
$$

